\title{
Article \\ Effect of Pre-Fermentative Maceration and Fining Agents on Protein Stability, Macromolecular, and Phenolic Composition of Albariño White Wines: Comparative Efficiency of Chitosan, k-Carrageenan and Bentonite as Heat Stabilisers
}

\author{
Inma Arenas ${ }^{1,+}$, Miguel Ribeiro ${ }^{1,+}$, Luís Filipe-Ribeiro ${ }^{1}{ }^{10}$, Rafael Vilamarim ${ }^{1}$, Elisa Costa ${ }^{1}$, João Siopa ${ }^{1}$, \\ Fernanda Cosme ${ }^{1,2} \mathbb{D}$ and Fernando M. Nunes $1,3, * \mathbb{D}$
}

1 Chemistry Research Centre-Vila Real (CQ-VR), Food and Wine Chemistry Lab., University of Trás-os-Montes and Alto Douro, 5000-801 Vila Real, Portugal; inmarenas@hotmail.com (I.A.); jmribeiro@utad.pt (M.R.); fmota@utad.pt (L.F.-R.); rafa_vilamarim_93@hotmail.com (R.V.); ecmatos@gmail.com (E.C.); joaosiopa2109@hotmail.com (J.S.); fcosme@utad.pt (F.C.)

2 Biology and Environment Department, School of Life Sciences and Environment, University of Trás-os-Montes and Alto Douro, 5000-801 Vila Real, Portugal

check for updates

Citation: Arenas, I.; Ribeiro, M.; Filipe-Ribeiro, L.; Vilamarim, R.; Costa, E.; Siopa, J.; Cosme, F.; Nunes, F.M. Effect of Pre-Fermentative Maceration and Fining Agents on Protein Stability, Macromolecular, and Phenolic Composition of Albariño White Wines: Comparative Efficiency of Chitosan, k-Carrageenan and Bentonite as Heat Stabilisers. Foods 2021, 10, 608. https://doi.org/ $10.3390 /$ foods 10030608

Academic Editors: Andrea Curioni and Simone Vincenzi

Received: 15 February 2021

Accepted: 9 March 2021

Published: 12 March 2021

Publisher's Note: MDPI stays neutral with regard to jurisdictional claims in published maps and institutional affiliations.

Copyright: (c) 2021 by the authors. Licensee MDPI, Basel, Switzerland. This article is an open access article distributed under the terms and conditions of the Creative Commons Attribution (CC BY) license (https:// creativecommons.org/licenses/by/ $4.0 /)$
3 Chemistry Department, School of Life Sciences and Environment, University of Trás-os-Montes and Alto Douro, 5000-801 Vila Real, Portugal

* Correspondence: fnunes@utad.pt; Fax: +351-2593-50480

+ Both authors contributed equally to this work.

\begin{abstract}
In this work, the effect of pre-fermentative skin maceration (PFSM) on the chemical composition of the macromolecular fraction, polysaccharides and proteins, phenolic compounds, chromatic characteristics, and protein stability of Albariño monovarietal white wines was studied. PFSM increased the extraction of phenolic compounds and polysaccharides and reduced the extraction of pathogenesis-related proteins (PRPs). PFSM wine showed significantly higher protein instability. Sodium and calcium bentonites were used for protein stabilisation of wines obtained with PFSM (+PFSM) and without PFSM (-PFSM), and their efficiencies compared to fungal chitosan (FCH) and k-carrageenan. k-Carrageenan reduced the content of PRPs and the protein instability in both wines, and it was more efficient than sodium and calcium bentonites. FCH was unable to heat stabilise both wines, and PRPs levels remained unaltered. On the other hand, FCH decreased the levels of wine polysaccharides by $60 \%$. Sodium and calcium bentonite also decreased the levels of wine polysaccharides although to a lower extent (16\% to 59\%). k-Carrageenan did not affect the wine polysaccharide levels. Overall, k-carrageenan is suitable for white wine protein stabilisation, having a more desirable impact on the wine macromolecular fraction than the other fining agents, reducing the levels of the wine PRPs without impacting polysaccharide composition.
\end{abstract}

Keywords: Albariño white wine; k-carrageenan; fungal chitosan; sodium bentonite; calcium bentonite; protein stability; protein profile; polysaccharides; chromatic characteristics; phenolic compounds

\section{Introduction}

In winemaking, pre-fermentative skin maceration (PFSM) is a process applied to white wine production where the skins of crushed and destemmed white grapes are macerated in their juice at controlled conditions (time and temperature) before pressing. This process aims to obtain the maximum intensity of varietal aroma and to improve white wine quality [1,2]. Nevertheless, skin maceration also increases the levels of phenolic compounds extracted increasing wine bitterness, astringency, and browning potential [3-5]. Also, the higher levels of potassium ions extracted enhance potassium bitartrate precipitation, reducing tartaric acid concentration, resulting in lower titratable acidity and higher $\mathrm{pH}$, 
and consequently perceived sourness is diminished [6-8]. Ramey et al. [3] using different maceration temperatures $\left(9^{\circ} \mathrm{C}\right.$ and $\left.15^{\circ} \mathrm{C}\right)$ showed that the wine $\mathrm{pH}$ increased from 3.33 to 3.49 , respectively, and this would affect the protein stability, also the protein concentration increased 50\% (21.9 to $31.6 \mathrm{mg} / \mathrm{L}$ ). Likewise, Tian et al. [5] showed that the amount of protein increased in juice obtained with PFSM, particularly the pathogenesis-related proteins (PRPs).

PRPs are the main determinants of white wine protein instability, being grape-derived proteins with high molecular weight and low isoelectric point, and include the chitinases and thaumatin-like proteins [9-11]. These proteins can be responsible for a wine's colloidal instability, producing a suspended and undesirable haze, and forming amorphous sediment or flocculate, before or after bottling [9,12-15]. This instability can cause serious economic losses to the wine producers. Wine protein haze formation can occur under high temperatures, throughout storage, or wine transportation due to the protein selfaggregation phenomena, resulting in light-dispersing particles [16]. Protein instability can also occur through the blending of protein stable wines. This phenomenon needs to be prevented by removing them from the wine, usually by fining, before wine bottling $[17,18]$. Bentonite fining is the most effective and used process to avoid protein instability in white wine [19-21]. However, bentonite fining can affect wine quality, for example, by removal of colour, aroma, and flavour compounds [14,22-25] affecting the wine sensory characteristic [26]. Also, the application of high doses of bentonite produces bentonite lees that can comprise $5 \%$ to $20 \%$ of the wine volume associated with the poor settling characteristics [27] and presents additional waste disposal challenges [14,28]. Therefore, alternative techniques to bentonite fining for this goal have been studied, such as chitin and chitosan $[29,30]$, carrageenan [15,31], and the use of mannoproteins [32,33]. The use of chitosan in winemaking has been authorised by the European Union (EU) for heavy metals and contaminant removal, prevention of cloudiness, and reduction of undesirable Brettanomyces spp. population [34]. For wine applications, only chitin (Oeno 367-2009 Chitin-Glucan [35]) and chitosan (Oeno 368-2009 Chitosan [35]) obtained from the cell walls of Aspergillus niger or Agaricus bisporus are authorised. Fungal chitin shows some special features, concerning the chemical structure and biosynthesis [36] when compared to crustacean chitins. However, a major difference results from the fact that fungal chitin is associated with other polysaccharides which do not occur in the exoskeleton of arthropods [36,37]. Furthermore, chitins and chitosans can present a diversity of structural features like their deacetylation degree and molecular weight that can affect their properties like charge density and solubility [36,37]. Chitin can remove specific wine proteins, namely the grape class IV chitinases [38]. The application of $1 \mathrm{~g} / \mathrm{L}$ of chitin reduced the wine haze induced by the heat test by $50 \%$, while the application of $20 \mathrm{~g} / \mathrm{L}$ of chitin reduced the haze by $80 \%$. This haze reduction observed was directly linked to the elimination of the class IV grape chitinases. Colangelo et al. [30] also observed that wines treated with $1 \mathrm{~g} / \mathrm{L}$ of fungal chitosan-glucan improved heat stability at $55-62{ }^{\circ} \mathrm{C}$ and this was also due to the specific elimination of chitinases. On the other hand, carrageenan due to their negative charge at low $\mathrm{pH}$ can electrostatically flocculate and sediment positively charged proteins responsible for wine protein instability [15,31,39,40]. Cabello-Pasini et al. [39] showed that carrageenan removed the same protein fractions adsorbed by bentonite, establishing that carrageenan might have a higher wine stabilisation efficiency without changing the wine tannin concentration when compared to bentonite fining. Marangon et al. [15,40], also observed that carrageenan has no adverse sensory impacts compared to wine fined with bentonite. In addition, the wine treated with carrageenan did not increase lees volume comparative to bentonite fining. Likewise, Ratnayake et al. [31] used commercially carrageenan's to understand the protein stabilisation efficiency and the impact on wine sensory characteristics. From the different commercial carrageenan's tested two of them were able to heat $\left(80^{\circ} \mathrm{C} / 2 \mathrm{~h}, 20^{\circ} \mathrm{C} / 3 \mathrm{~h}\right)$ stabilise the white wine without negative impacts on the wine's sensory characteristics. However, if carrageenan is applied to the wine, there is a risk of obtaining wines that are unstable by performing the protein stability (heat test) 
due to carrageenan remaining in wine, contributing to haze formation in the heat test and also the wine presenting a lower filterability mainly when carrageenan is applied before or during fermentation [15,40]. According to Ratnayake et al. [31], the wine filterability differs with the carrageenan structure and time of application. Therefore, the application of carrageenan's for white wine protein stabilisation has shown to be effective when applied either during wine processing or to the finished wine $[15,39,40]$. Although the impact of these fining agents on protein concentration has been studied, their impact on wine polysaccharides, the other macromolecular component of wines, is largely unknown. Wine polysaccharides have their origin in grape cell walls and comprise polysaccharides rich in arabinose and galactose (arabinans, type I arabinogalactans, and type II arabinogalactan proteins) and type I and type II rhamnogalacturonans [41,42]. These polysaccharides are released in white winemaking when grape skins and grape cell solids are in contact with the juice before fermentation [41,42]. Another wine polysaccharides are derived from the yeast cell walls during fermentation and ageing on lees, such as mannoproteins and glucans [41]. The amount and type (chemical composition, molecular structure, and origin), of wine polysaccharides, influence wine properties and sensory characteristics [43,44]. Wine polysaccharides are important to stabilise other molecules, avoiding or delaying aggregation and flocculation and consequently haze formation $[45,46]$. According to Gawel et al. [42], the wine polysaccharide structures' diversity and complexity give them the ability to form intermolecular associations with other wine compounds responsible for wine mouthfeel either through hydrogen bonding or hydrophobic interactions. The white winemaking operations related to juice extraction such as pre-fermentation skin maceration, skin, and whole-bunch pressing, yielded differences in the polysaccharide's concentration around 15\% [47]. However, the effect of polysaccharides on white wine mouthfeel and the taste was slight compared with that of the wine matrix components of alcohol and $\mathrm{pH}$ [42].

Thus, this work aimed to study the effect of the skin contact on Albariño monovarietal white wines obtained with and without pre-fermentative skin maceration on the wine macromolecular fractions, proteins and polysaccharides, phenolic compounds, chromatic characteristics, and protein stability. Also, the efficiency of fungal chitosan and $\mathrm{k}$-carrageenan on wine protein stability as alternative fining agents to sodium and calcium bentonites were studied, as well the impact on the wine polysaccharides.

\section{Materials and Methods}

\subsection{Winemaking Technology and Wine Composition}

The Albariño monovarietal white grapes, used in this study for the production of the white wines remained in the harvest boxes for $10 \mathrm{~h}$ in a cold chamber at $5^{\circ} \mathrm{C}$. The grapes were then destemmed/crushed and potassium metabisulfite $(10 \mathrm{~g} / \mathrm{hL}$, Agrovin, Ciudad Real, Spain), enzymes (pectin lyase and polygalacturonase, $0.4 \mathrm{~mL} / \mathrm{hL}$, Enozym Lux, Agrovin, Ciudad Real, Spain), and hydrolysable gallic tannin (3 g/hL, Galitan, Agrovin, Spain) were added. To produce the white wine without pre-fermentative skin maceration (-PFSM), the crushed grapes were pressed in an inert atmosphere of $\mathrm{CO}_{2}$ with the addition of enzymes (pectolytic enzymes, pectin lyase, polygalacturonase, pectinesterase, and cellulases, $2 \mathrm{~g} / \mathrm{hL}$, Enozym Éclair-AEB). Then the clarified grape juice inoculated with active dry yeasts (Saccharomyces spp., $20 \mathrm{~g} / \mathrm{hL}$, Viniferm Elegancia, Ciudad Real, Spain), and the alcoholic fermentation was performed at a controlled temperature $\left(14-15^{\circ} \mathrm{C}\right)$. At 1080 specific gravity the grape must was supplemented with ammonium phosphate, inactivated yeasts, and thiamine at $5 \mathrm{~g} / \mathrm{hL}$ (Actimax Plus, Agrovin, Ciudad Real, Spain) and at 1054 specific gravity supplemented with organic nitrogen, and vitamins at $10 \mathrm{~g} / \mathrm{hL}$ (Actimax Vit, Agrovin, Ciudad Real, Spain). The alcoholic fermentation finished when residual sugars were $<2 \mathrm{~g} / \mathrm{L}$. For the Albariño monovarietal white wine with pre-fermentative skin maceration (+PFSM) after destemming/crushing and before pressing the grape juice remained in contact with the grape skin and seeds, during $8 \mathrm{~h}$ at a temperature of $5{ }^{\circ} \mathrm{C}$, all the other operations were unchanged. The final wine oenological parameters shown in Table 1 were analysed using a Fourier transform infrared spectroscopy (FTIR) Bacchus 
Micro (Microderm, Paris, France). The wine was stored in stainless steel tanks of 7000 litters protected with sulphur dioxide at $50 \mathrm{mg} / \mathrm{L}$ (free sulphur dioxide).

Table 1. Physicochemical characteristics from the Albariño monovarietal white wine with and without pre-fermentative skin maceration (PFSM) used in the experiments.

\begin{tabular}{lcc}
\hline Albariño Monovarietal White Wine & $\begin{array}{c}\text { With Pre-Fermentative Skin Maceration } \\
\text { (+PFSM) }\end{array}$ & $\begin{array}{c}\text { Without Pre-Fermentative Skin Maceration } \\
(- \text { PFSM) }\end{array}$ \\
\hline Alcohol content $(\% v / v)$ & 13.6 & 14.3 \\
\hline Density at $20^{\circ} \mathrm{C}\left(\mathrm{g} / \mathrm{cm}^{3}\right)$ & 0.9888 & 7.9883 \\
\hline $\begin{array}{l}\text { Titratable acidity }(\text { expressed as g/L } \\
\text { tartaric acid) }\end{array}$ & 6.2 & 3.52 \\
\hline $\mathrm{pH}$ & 3.81 & 0.45 \\
\hline $\begin{array}{l}\text { Volatile acidity (expressed as g/L } \\
\text { acetic acid) }\end{array}$ & 0.42 & 22.2 \\
\hline Protein instability (Heat-test, $\Delta \mathrm{NTU})$ & 26.6 & \\
\hline
\end{tabular}

\subsection{Fining Experiments}

Albariño monovarietal white wine obtained without pre-fermentative skin maceration $(-\mathrm{PFSM})$ and with pre-fermentative skin maceration $(+\mathrm{PFSM})$ were fined with fungal chitosan (No Brett Inside, Lallemand, Midi-Pyrénées, France; 100 g/hL), within the limits allowed by the International Organisation of Vine and Wine (OIV) to avoid instabilities [34], k-carrageenan (CEAMSA, Pontevedra, Spain; $100 \mathrm{~g} / \mathrm{hL}$ ), sodium bentonite (SAIstab ${ }^{\circledR}$ BENTO MDP, SAI Enology, Paredes, Portugal; $120 \mathrm{~g} / \mathrm{hL}$ ), and calcium bentonite (SAIstab ${ }^{\circledR}$ BENTO CLS, SAI Enology, Paredes, Portugal; $120 \mathrm{~g} / \mathrm{hL}$ ) using the maximum dosage recommended by the manufacturer, since there are no official limits for their application in wines. Before use, sodium and calcium bentonites were hydrated in water for $8 \mathrm{~h}$ at a ratio of 1:20. Fungal chitosan was dispersed in water at $3.125 \%$ before use. $\mathrm{k}$-Carrageenan was added directly to the wine. The fining experiments were conducted in $250 \mathrm{~mL}$ graduated cylinders by mixing the wine with the fining agent and allowing the mixture to remain in contact with the wines for 7 days at $20^{\circ} \mathrm{C}$, simulating the standard oenological practices. Before fining the level of free sulphur dioxide was adjusted to $50 \mathrm{mg} / \mathrm{L}$, if needed, and the graduate cylinders were closed with Parafilm ${ }^{\circledR} \mathrm{M}$ (Merck, Darmstadt, Germany). Wine samples without pre-fermentative skin maceration (-PFSM) and with pre-fermentative skin maceration $(+\mathrm{PFSM})$ without the addition of a fining agent were used as a control. The samples were centrifuged at $537.6 \mathrm{~g}$ for $15 \mathrm{~min}$ before analysis. All experiments were performed in duplicate.

\subsection{Macromolecular Material Isolation}

For the isolation of the wine macromolecular material that includes wine protein and polysaccharides, to $100 \mathrm{~mL}$ of controls and treated-samples was added urea to a final concentration of $6 \mathrm{M}$. This initial step was conducted to reduce non-covalent interactions between proteins and polyphenols. Then, this mixture was subjected to ultrafiltration (molecular weight cut-off $10 \mathrm{kDa}$ ) up to the volume of approximately $5 \mathrm{~mL}$ [48]. To remove urea from the solution, this volume was made up to $100 \mathrm{~mL}$ with ultrapure water at least 5 times. Finally, a volume of about $10 \mathrm{~mL}$ was recovered and freeze-dried yielding the wine macromolecular material.

\subsection{Electrophoresis (Sodium Dodecyl Sulphate Polyacrylamide Gel Electrophoresis (SDS-PAGE)}

Wine macromolecular material, containing wine proteins, was diluted in sample buffer containing $2 \%(w / v)$ sodium dodecyl sulphate (SDS), $40 \%(v / v)$ glycerol, $0.02 \%$ $(w / v)$ bromophenol blue, $0.08 \mathrm{M}$ Tris- $\mathrm{HCl} \mathrm{pH} \mathrm{8.0,} \mathrm{heated} \mathrm{at} 70{ }^{\circ} \mathrm{C}$ during $10 \mathrm{~min}$ and separated in a resolving gel with $16 \%$ total monomer concentration (T) using a Hoefer SE 
600 Ruby unit (Amersham Biosciences, Uppsala, Sweden) at $30 \mathrm{~mA} /$ gel. The gels were stained with Coomassie Blue R-250 for $24 \mathrm{~h}$ and then washed in distilled water overnight.

\subsection{Protein Quantification}

Wine total protein concentration was determined by the Bradford assay modified by Read and Northcote [49]. Briefly, dye-reagent was prepared using $0.01 \%(w / v)$ Serva Blue G (Heidelberg, Germany) in 1.6 M phosphoric acid/0.8 M ethanol. The assay was performed in 1-mL glass cuvette, which was washed with ethanol followed by distilled water between samples. For wine macromolecular material, containing wine proteins, dye-reagent $(950 \mu \mathrm{L})$ was added to $50 \mu \mathrm{L}$ of protein solution $(0.5 \% w / v$ in ultrapure water). In the case of direct analysis of wines, dye-reagent $(1000 \mu \mathrm{L})$ was added to $200 \mu \mathrm{L}$ of white wines. After $4 \mathrm{~min}$ absorbance was measured at $595 \mathrm{~nm}$. Samples were assayed in duplicate. Development of a standard curve for the semi-quantitative procedure was done using increasing bovine serum albumin (BSA) concentrations. Glass tubes were always chosen instead of plastic tubes.

\subsection{Reversed Phase-High Performance Liquid Chromatography (RP-HPLC) Quantitative Protein Analysis}

Wine macromolecular material, containing wine proteins, was solubilized in ultrapure water $(0.5 \% w / v)$ and separated by reversed phase-high performance liquid chromatography (RP-HPLC). For RP-HPLC analysis, an RP-C8 column was used $(25 \mathrm{~cm}, 4.5 \mathrm{~mm}$ internal diameter (i.d.), $51 \mathrm{~m}$, Macherey-Nagel, Germany) maintained at $35^{\circ} \mathrm{C}$ during the separation process, and an injection volume of $100 \mu \mathrm{L}$ was used. A gradient elution was performed; eluent A consisting of $0.1 \%(v / v)$ aqueous trifluoroacetic acid and eluent B consisting of acetonitrile and trifluoroacetic acid $(99.9 / 0.1 \%, v / v)$, with following elution program: $0 \min 20 \%$ B, 7 min 40\% B, $15 \min 50 \%$ B, $16 \min 55 \%$ B, $30 \min 66 \%$ B, 35 min 66\% B, $36 \mathrm{~min} 20 \% \mathrm{~B}, 42 \mathrm{~min} 20 \% \mathrm{~B}$; flow rate of $1 \mathrm{~mL} / \mathrm{min}$. Detection was made by ultraviolet (UV) absorbance at $210 \mathrm{~nm}$. Development of a standard curve for the RP-HPLC quantitative procedure was conducted using increasing BSA concentrations. Protein identification was performed using the data reported in the literature [50,51].

\subsection{Protein Heat-Stability Test}

The efficacy of different fining agents (sodium bentonite, calcium bentonite, fungal chitosan, and carrageenan) in producing heat-stabilised wines were assessed in trials with an Albariño monovarietal white wine obtained without pre-fermentative skin maceration (-PFSM) and with pre-fermentative skin maceration (+PFSM). Samples were filtered at $0.45 \mu \mathrm{m}$ (Ultipor N66, Pall Corporation, New York, NY, USA) and assessing the heat stability of each sample $\left(80{ }^{\circ} \mathrm{C}\right.$ for $30 \mathrm{~min}$ ) according to Dubourdieu et al. [52]. If the difference $(\triangle N T U)$ in nephelometric turbidity unit (NTU), between the heated and unheated samples, was higher than 2 NTU units, means that the wine sample is unstable [52]. All analyses were performed in duplicate.

\subsection{Filterability Index}

The filterability index of the wines was measured according to Descout et al. [53]. Wine (approximately $700 \mathrm{~mL}$ ) was added to a stainless-steel chamber and filtered through a disc filter [ $0.45 \mu \mathrm{m}$ polyethersulfone membrane, Millipore Express] under pressure ( 2 bar) and collected in a measuring cylinder. The time in seconds taken to filter $200 \mathrm{~mL}$ and $400 \mathrm{~mL}$ of wine was recorded to calculate the filterability index (FI), where FI > 20 was indicative of filtration issues. Analyses were performed in triplicate.

$$
\mathrm{FI}=\mathrm{T} 400-2 \mathrm{~T} 200
$$

\subsection{Quantification of Non-Flavonoids, Flavonoids and Total Phenols}

The phenolic content of the wines was quantified using the absorbance at $280 \mathrm{~nm}$ before and after precipitation of the flavonoid phenols, through reaction with formaldehyde, 
according to Kramling and Singleton [54]. The non-flavonoid phenolic compounds of the white wine were quantified according to Kramling and Singleton [54], and the total phenolic compounds, were also determined by a spectrophotometric method, using an ultravioletvisible (UV-vis) spectrophotometer according to Ribéreau-Gayon et al. [55]. The flavonoid phenolic compounds were obtained by the difference between total phenolic compounds and non-flavonoid phenolic compounds [54]. Quantifications were performed using the calibration curve of gallic and the results were expressed as gallic acid equivalents/L. All analyses were performed in duplicate.

\subsection{Chromatic Characteristics and Colour $\left(A_{420 \mathrm{~nm}}\right)$}

Absorption spectra of wine samples were scanned from $380 \mathrm{~nm}$ to $780 \mathrm{~nm}$, using a $1 \mathrm{~cm}$ path length quartz cell, and the chromatic characteristics of wines $\mathrm{L}^{*}$ (lightness), $\mathrm{a}^{*}$ (redness), and $\mathrm{b}^{*}$ (yellowness) coordinates were calculated using the CIELab colour space method according to OIV [56]. The colour difference between the wine sample after oxidation and the control wine was calculated using the following equation: $\Delta \mathrm{E}^{*}=\left[\left(\Delta \mathrm{L}^{*}\right)^{2}+\left(\Delta \mathrm{a}^{*}\right)^{2}+\left(\Delta \mathrm{b}^{*}\right)^{2}\right]^{1 / 2}$. Colour differences higher than 2 units can be distinguished by the human eye [57]. The white wine colour was determined by measuring absorbance at $420 \mathrm{~nm}$ (1 cm cell) as described in the OIV methods [56]. All analyses were performed in duplicate.

\subsection{High-Performance Liquid Chromatography (HPLC) Analysis of Catechin and Phenolic Acids}

The analysis of phenolic acids and catechin of white wines was performed by Reversed Phase (C-18 stationary phase, $250 \mathrm{~mm} \times 4.6 \mathrm{~mm}, 5 \mu \mathrm{m}$ particle size, ACE, Scotland) High Performance Liquid Chromatography (Ultimate 3000 Dionex, Thermo Fisher Scientific, Waltham, MA, USA) with photodiode array detection (200 to $650 \mathrm{~nm}$, PDA-100, Ultimate 3000 Dionex, Thermo Fisher Scientific, Waltham, MA, USA). Before analysis the wine was concentrated 25 fold by vacuum evaporation ( $50 \mathrm{~mL}$ of wine: $2 \mathrm{~mL}$ of methanol:water 1:1), and a $50 \mu \mathrm{L}$ injection volume was used. During separation the column temperature was set at $35^{\circ} \mathrm{C}$ and a $1 \mathrm{~mL} / \mathrm{min}$ flow rate was used. The elution was performed using $5 \%$ aqueous formic acid (A) and methanol (B) and the following gradient was used: $5 \% \mathrm{~B}(0-5 \mathrm{~min})$; 5-65\% B (5-65 $\mathrm{min}) ; 65 \%$ to 5\% (65-67 $\mathrm{min}$ ) [58]. Quantification was performed with calibration curves with pure commercial standards when available (caffeic acid, coumaric acid, ferulic acid, gallic acid, and catechin). The calibration curve of caffeic acid was used for the quantification of trans-caftaric acid, 2-S-glutathionylcaftaric acid (GRP), and caffeic acid ethyl ester. The calibration curve of $p$-coumaric acid was used for the quantification of coutaric acid and coumaric acid ethyl [59,60]. Analyses were performed in duplicate.

\subsection{Polysaccharides Sugar Composition and Content}

The sugar composition of wine polysaccharides was determined after acid hydrolysis with $1 \mathrm{M} \mathrm{H}_{2} \mathrm{SO}_{4}$ at $100{ }^{\circ} \mathrm{C}$ during $2.5 \mathrm{~h}$ by anion-exchange chromatography with pulsed amperometric detection (ICS-3000, Dionex, with an electrochemical detector (ED) containing an $\mathrm{Au}$ working electrode, $\mathrm{Ag} / \mathrm{AgCl}$ reference electrode, and Ti counter electrode) according to Fraga and Nunes [61].

Quantification was performed by the internal standard method using 2-deoxyglucose as internal standard and the calibration curve method $(0.25-2.5 \mathrm{mg}$ of sugar $/ 0.5 \mathrm{mg}$ of internal standard) with pure commercial standards of fucose, rhamnose, arabinose, galactose, glucose, mannose, xylose, galacturonic, and glucuronic acid standards. Separation was performed with a CarboPac PA-20 column $(150 \mathrm{~mm} \times 3 \mathrm{~mm})$ with a CarboPac PA20 pre-column (Dionex, Sunnyvale, CA, USA) maintained at $35^{\circ} \mathrm{C}$ during the run. The eluents were keep under nitrogen. Elution was performed using three solutions: eluent A $1.25 \mathrm{mM} \mathrm{NaOH}$ solution containing $2 \mathrm{mM} \mathrm{Ba}(\mathrm{OH})_{2}$, eluent $\mathrm{B}-400 \mathrm{mM}$ sodium acetate containing $2 \mathrm{mM} \mathrm{Ba}(\mathrm{OH})_{2}$ and eluent $\mathrm{C}-500 \mathrm{mM} \mathrm{NaOH}$ containing $2 \mathrm{mM} \mathrm{Ba}(\mathrm{OH})_{2}$, using the following elution program: 0-19 $\mathrm{min}, 100 \% \mathrm{~A}, 0 \% \mathrm{~B}, 0 \% \mathrm{C}, 19-27 \mathrm{~min} 50 \% \mathrm{~A}, 50 \% \mathrm{~B}$, $0 \% \mathrm{C}, 27-37 \mathrm{~min}$; increase to $10 \% \mathrm{~A}, 50 \% \mathrm{~B}, 40 \% \mathrm{C} ; 37-47 \mathrm{~min} 60 \% \mathrm{~A}, 0 \% \mathrm{~B}, 40 \% \mathrm{C}$ and 
maintained until $57 \mathrm{~min}$. The column was conditioned with $100 \% \mathrm{~A}, 0 \% \mathrm{~B}, 0 \% \mathrm{C}$ for $15 \mathrm{~min}$ before injection. The injection volume was $5 \mu \mathrm{L}$, the flow rate was $0.3 \mathrm{~mL} / \mathrm{minThe}$ ED cell waveform was $+0.1 \mathrm{~V}$ from 0.00 to $0.40 \mathrm{~s}$, then $-2.0 \mathrm{~V}$ from 0.41 to $0.42 \mathrm{~s}$, and a ramp -2.0 to $+0.6 \mathrm{~V}$ from 0.42 to $0.43 \mathrm{~s}$, followed by $-0.1 \mathrm{~V}$ from 0.44 to $0.50 \mathrm{~s}$ (end of cycle). The integration region was from 0.2 to $0.4 \mathrm{~s}$. All analyses were performed in duplicate.

\subsection{Statistical Analysis}

The results are presented as means \pm standard deviation. Physicochemical data were statistically tested by the Student $t$-test when comparing two independent samples and by analysis of variance (ANOVA) when comparing more than two independent samples. Tukey's honestly significant difference (HSD, 5\% level) post-hoc test was applied to physicochemical data to determine significant differences. The differences were considered statistically significant when $p$ values were less than 0.05 . These analyses were performed using Statistica 10 software (StatSoft, Tulsa, OK, USA).

\section{Results and Discussion}

\subsection{Protocol for the Isolation of the White Wine Macromolecular Components}

Proteins and polysaccharides are the two main and almost exclusive components of the macromolecular fraction of white wines. In white wines, they are present in low concentrations when compared to the low molecular components like tartaric acid, residual sugars, and even phenolic compounds. Typically, white wine protein contents range between 15 and $500 \mathrm{mg} / \mathrm{L}$ [9,14,29,49,62,63], and white wines polysaccharides from 50 to $150 \mathrm{mg} / \mathrm{L}[64,65]$. The first step for studying the macromolecular components of wines is being able to concentrate and remove potential interfering compounds that would affect their characterisation, for example, in the analysis of proteins. The analysis of PRPs, the main culprits for protein instability in wines, have been widely performed by RP-HPLC. However, sample preparation for chromatographic separation varies between studies and according to their purpose. For quantitative purposes, direct injection has been used $[50,66]$. Other authors opted for prior protein precipitation using ammonium sulphate and subsequent hydrophobic interaction chromatography (HIC) fractionation before HPLC analysis [67]. Jaeckels et al. [48] used ultrafiltration to isolate and concentrate the high molecular weight material (HMWM) of wines (molecular mass cut-off of $10 \mathrm{kDa}$ ). In this work, our experimental design also included ultrafiltration for the isolation of the wine macromolecular components but with the addition of the chaotropic agent urea at $6 \mathrm{M}$ concentration. This served to reduce the non-covalent interactions between high molecular weight components, particularly proteins, and phenolic compounds present in wine, thus eliminated in the ultrafiltration step and allowing the purification of the high molecular weight fraction for subsequent studies without interferences. This is confirmed by the sodium dodecyl sulphate polyacrylamide gel electrophoresis (SDS-PAGE) result (Figure 1) which shows well-resolved protein bands without the interference of phenolic compounds that could alter their electrophoretic profile [68]. Also, the analysis of the extracts by RP-HPLC did not allow us to observe the presence of the common white wine phenolic compounds, showing the efficiency in their removal. Therefore, this protocol was used in the isolation of the macromolecular $(>10 \mathrm{kDa})$ components of white wines.

\subsection{Effect of the Skin Contact on the Albariño White Wine Protein Content, Heat Stability, and Efficiency of Protein Stabilisation by Fungal Chitosan, $k$-Carrageenan, and Bentonite}

The wine obtained without pre-fermentative skin maceration (-PFSM) presented a total protein content significantly higher than the wine obtained with pre-fermentative skin maceration (+PFSM; Figure 2). This can be due to the higher extraction of phenolic compounds from the skin during the pre-fermentative maceration which in turn can have insolubilised a higher amount of proteins when compared to the wines obtained without pre-fermentative maceration (further discussed below). Both wines presented significant protein instability, with the +PFSM wine showing a significantly higher protein instability, 
measured by the increase in wine turbidity after heating $30 \mathrm{~min}$ at $80^{\circ} \mathrm{C}$ when compared to the -PFSM counterpart (Figure 3). To stabilise the wines concerning their protein instability, four fining agents were compared concerning their efficiencies: two bentonites, one sodium, and one calcium bentonite, and two polysaccharides, fungal chitosan, and k-carrageenan.

(a)

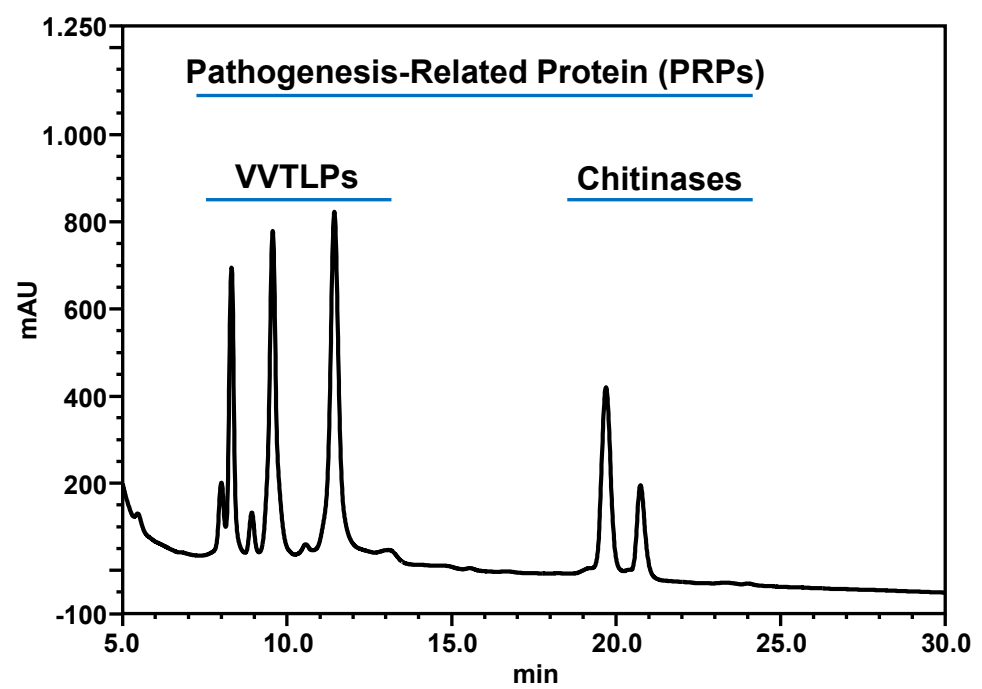

(b)

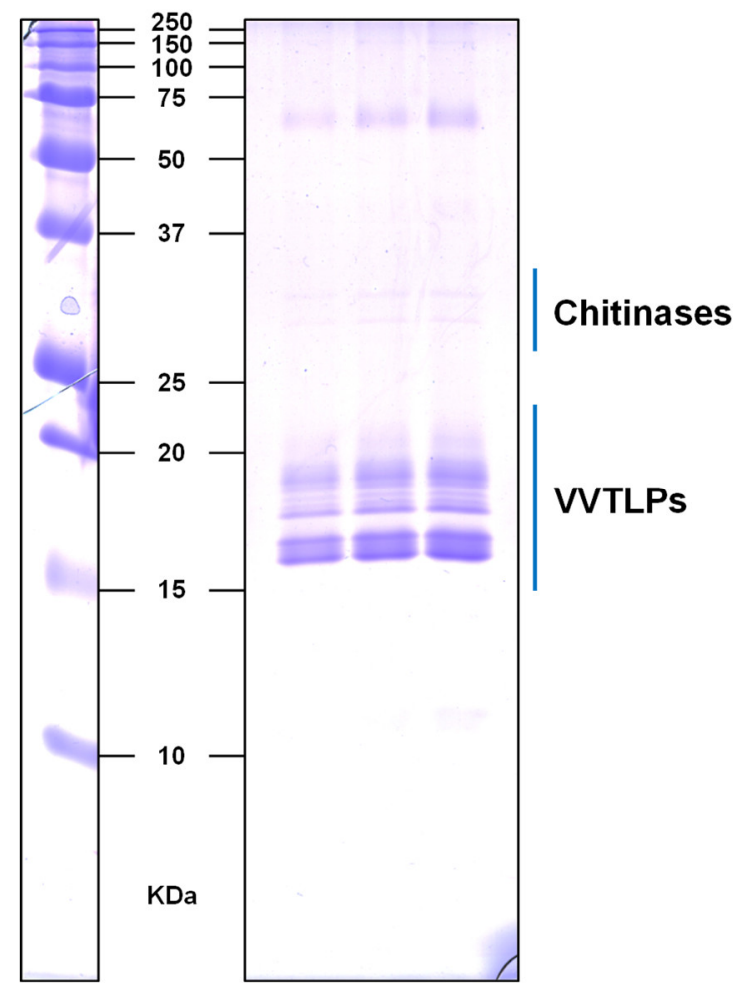

Figure 1. Reversed-phase high-performance liquid chromatography (HPLC) results for an example wine, showing the different pathogenesis-related proteins (PRPs), namely Vitis vinifera thaumatin-like (VVTL) and chitinases proteins. Absorbance was registered at $210 \mathrm{~nm}$ (a). Sodium dodecyl sulphate polyacrylamide gel electrophoresis (SDS-PAGE) of the same wine in increasing amount of protein $(5,7.5$, and $10 \mu \mathrm{g})$, showing the above-mentioned proteins $(\mathbf{b})$.

As can also be observed in Figure 3 the application of fungal chitosan $(100 \mathrm{~g} / \mathrm{hL})$, k-carrageenan $(100 \mathrm{~g} / \mathrm{hL})$, sodium bentonite $(120 \mathrm{~g} / \mathrm{hL})$, and calcium bentonite $(120 \mathrm{~g} / \mathrm{hL})$ decreased significantly the protein instability for both wines. Nevertheless, only the application of k-carrageenan was able to reduce the protein instability to stability levels $(\Delta$ NTU; Figure 3) $[52,69]$. The ability of k-carrageenan in increasing the heat stability of the wines was only observed when the wines were previously filtered to the determination of the turbidity. The centrifugation of wines before the heat stability test increased the wine turbidity (results not shown). This observation is in line with the results obtained by Ratnayake et al. [31], who observed that, after filtering, the k-carrageenan was able to further reduce the protein content of the wines. In both wines, sodium and calcium bentonite at the dosage used were not able to completely stabilise the wines, being more efficient in +PFSM than in - PFSM wine (Figure 3). The efficiency of both bentonites was not significantly different in stabilising the wines concerning protein stability. Of all the products tested, fungal chitosan was the least efficient product, presenting similar efficiencies in both wines (Figure 3). The efficiency of k-carrageenan for reducing protein instability in wines is in accordance with the results of Ratnayake et al. [31], who observed a similar performance for k-carrageenan and sodium bentonite. Nevertheless, in this work, k-carrageenan was more efficient than both sodium and calcium bentonites. The efficiency of chitosan was lower than that observed for sodium and calcium bentonites and much 
lower than that observed for k-carrageenan. This lower efficiency of chitosan is not in accordance with the results of Colangelo et al. [30], yet this difference may be related to the different protein stability tests used, as they used $60^{\circ} \mathrm{C}$ temperature and in this work, we used $80^{\circ} \mathrm{C}$ temperature for protein denaturation. Furthermore, it is known that Vitis vinifera thaumatin-like (VVTL) proteins (VVTLPs) are not denatured at $60^{\circ} \mathrm{C}$ and are denatured at $80{ }^{\circ} \mathrm{C}[12,70]$.

(a)

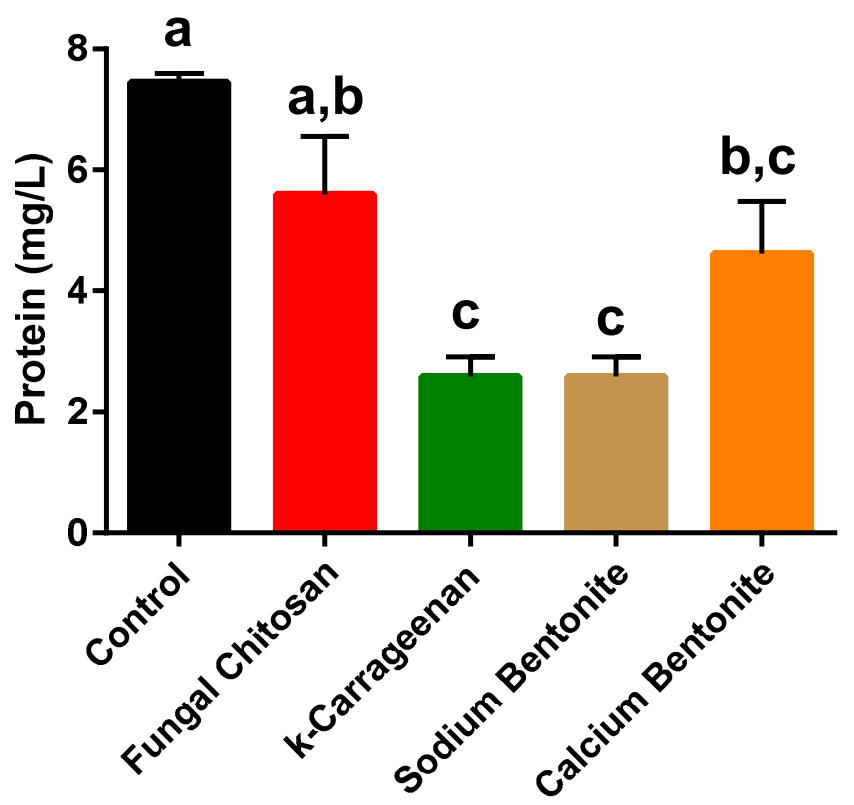

(b)

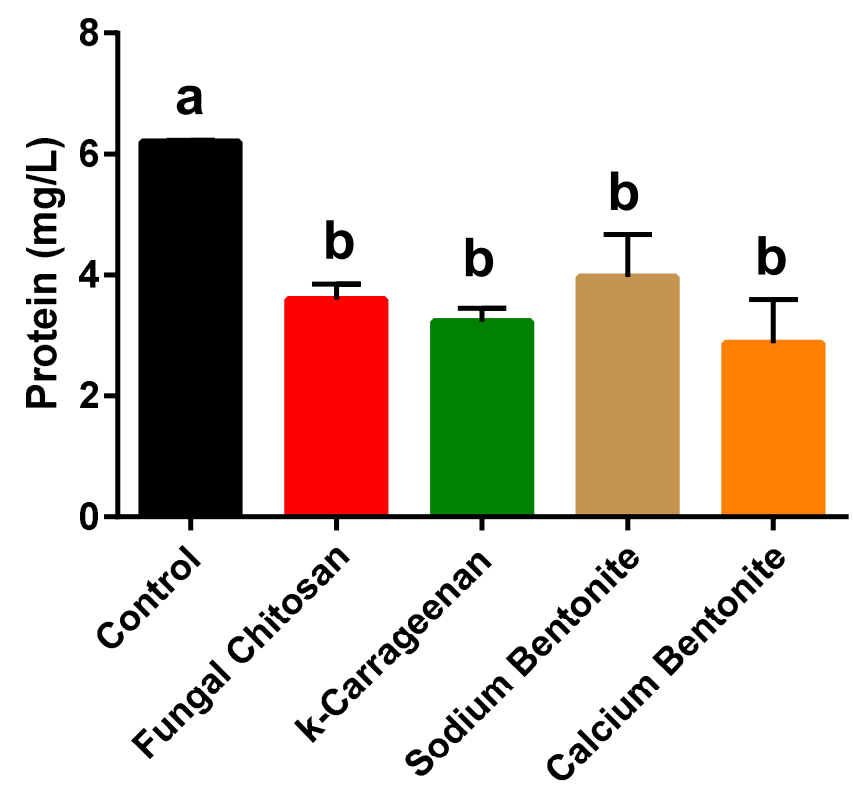

Figure 2. White wine protein content measured by the Bradford assay. (a) Albariño white wine without pre-fermentative skin maceration (-PFSM) and (b) Albariño white wine with pre-fermentative skin maceration (+PFSM). Fungal chitosan $(100 \mathrm{~g} / \mathrm{hL})$, k-carrageenan $(100 \mathrm{~g} / \mathrm{hL})$, sodium bentonite $(120 \mathrm{~g} / \mathrm{hL})$, and calcium bentonite $(120 \mathrm{~g} / \mathrm{hL})$. The columns values with the same letter are not statistically significant (Tukey $p<0.05)$.

To understand the differences observed in the protein stability of these two wines and the effect of the application of the different fining products, and especially the efficiency of kcarrageenan in the heat stabilisation of the wines, the total protein content was determined (Figure 2). The application of the different fining agents resulted in a significant decrease in the total protein content in +PFSM wine (Figure 2), whereas no significant results were found between the different treatments. On the other hand, for the -PFSM wine the application of fungal chitosan was not able to reduce significantly the total protein content (Figure 2). These results show that although the fining agents can decrease the total protein content of wines, depending on the wine matrix and fining agent, the decrease in total wine protein content does not allow us to explain the white wine protein stability (Figure 3). These results are in accordance with the results of Bayly and Berg [71] and Moretti and Berg [72] who found that the total protein content of wines was not related to their protein stability. 
(a)

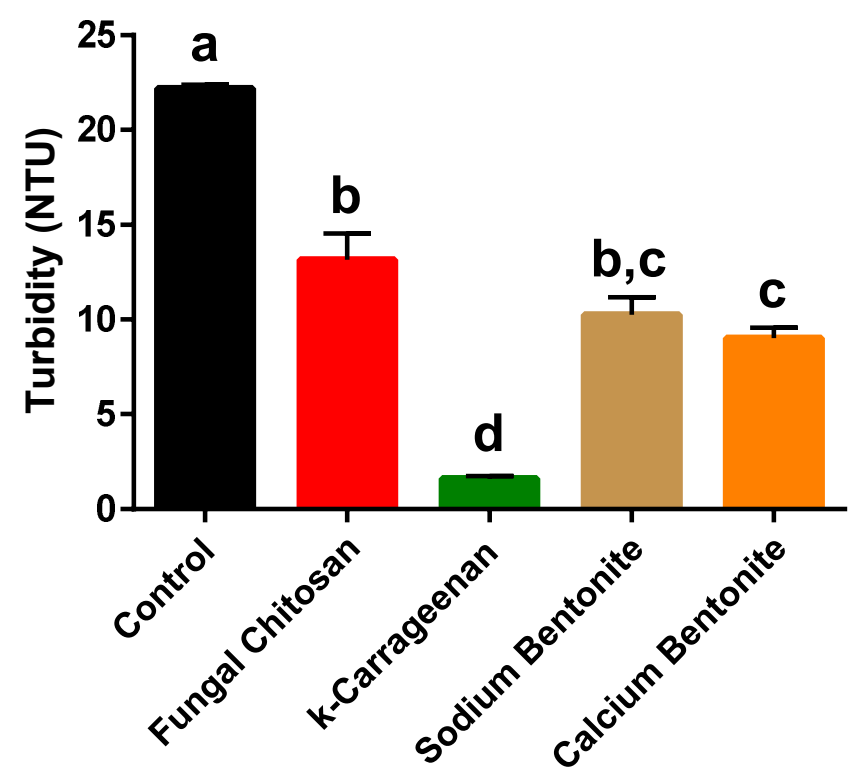

(b)

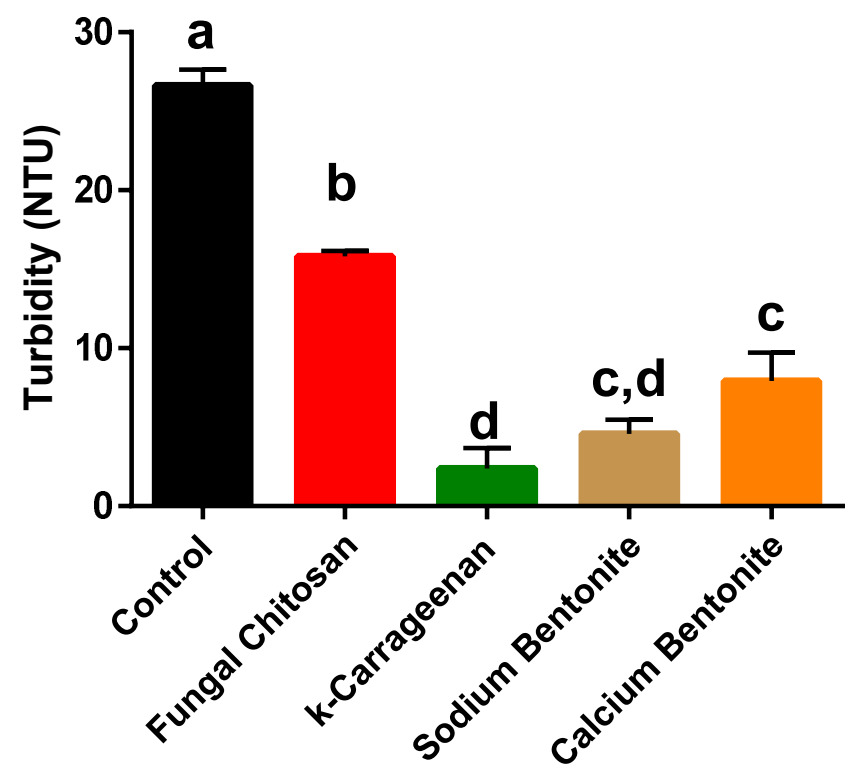

Figure 3. White wine protein stability measured by the increase in wine turbidity after heating for $30 \mathrm{~min}$ at $80{ }^{\circ} \mathrm{C}$. (a) Albariño white wine without pre-fermentative skin maceration (-PFSM) and (b) Albariño white wine with prefermentative skin maceration (+PFSM) Fungal chitosan $(100 \mathrm{~g} / \mathrm{hL})$, k-carrageenan $(100 \mathrm{~g} / \mathrm{hL})$, sodium bentonite $(120 \mathrm{~g} / \mathrm{hL})$, and calcium bentonite $(120 \mathrm{~g} / \mathrm{hL})$. The columns values with the same letter are not statistically significant (Tukey $p<0.05)$.

It has been shown that the most abundant haze-forming proteins include chitinases [73], along with VVTLPs and $\beta$-glucanases [74]. The wine protein instability may also be influenced by non-protein factors including the wine $\mathrm{pH}$, ionic strength [75], ethanol content, concentrations of polysaccharides [26,68], polyphenols [76], and sulphates [17]. Therefore, the content of VVTLPs and chitinases of +PFSM and -PFSM wines was determined by RP-HPLC (Figures 4 and 5). As can be observed, both wines contained significant amounts of VVTLPs and chitinases, with -PFSM wine presenting a significantly higher amount of both proteins, in line with the results obtained for the total wine protein content (Figure 2). The application of k-carrageenan, sodium, and calcium bentonite significantly decreased their contents when compared to control wine, with k-carrageenan showing the highest efficiency in the reduction of these two protein fractions for both wines (Figures 4 and 5). The ability of sodium and calcium bentonite for reducing the content of VVTLPs and chitinases in wines has already been observed by different authors [12,21,68]. At wine $\mathrm{pH}, \mathrm{VVTLPs}$ and chitinases present an overall positive charge, and bentonite is negatively charged, therefore the ability to remove VVTLPs and chitinases is attributed to the electrostatic interaction between these two proteins and bentonite [12]. The same mechanism can be hypothesised for the k-carrageenan. $\mathrm{k}$-Carrageenan is composed of a galactan backbone of alternating 1,3-linked- $\beta$-D-galactopyranosyl and 3,6-anhydro-D-galactose residues with one $\mathrm{SO}_{3}$ - residue per disaccharide; therefore, presenting a negative charge at wine $\mathrm{pH}$. The ability of k-carrageenan in increasing the white wine protein stability is in accordance with the results of Cabello-Pasini et al. [39], Marangon et al. [15,40], and Ratnayake et al. [31]. Nevertheless, as mentioned before, k-carrageenan was only able to stabilise the wines after filtration, being observed an increase in wine turbidity when the wines are centrifuged. This observation agrees with Ratnayake et al. [31]. On the other hand, fungal chitosan was unable to reduce the contents of these two protein fractions when compared to control. This result is partially in accordance with Colangelo et al. [30]. These authors showed that chitosan was unable to remove VVTLPs, while able to reduce chitinases. This difference can be due to the chemical composition of the wines used in this 
study and to the relative amount of chitinases in the wines analysed. Therefore, the differences in the relative efficiency of chitosan, k-carrageenan, sodium bentonite, and calcium bentonite in the stabilisation of white wine protein precipitation can be explained by the relative removal efficiency of these two pathogenesis-related proteins, and the different behaviour observed in the two wines obtained by different treatments is also explained by the relative amount of these proteins in both wines.

\subsection{Effect of $k$-Carrageenan Addition on Wine Filterability}

As described above, the wine protein stabilisation using k-carrageenan was only possible after wine filtration, and therefore the impact of its application on the wine filterability index was determined (Figure 6). The addition of k-carrageenan to both wines significantly increased their filterability index. These results are in accordance with Marangon et al. [15] and Ratnayake et al. [31] indicating that the addition of k-carrageenan to wines decreases its filterability. Nevertheless, the filterability index obtained after the addition of k-carrageenan was well below 20, a value that is taken as a limit for the wine filterability. In this sense, no problems of filterability are anticipated with the application of $\mathrm{k}$-carrageenan to wines.

(a)

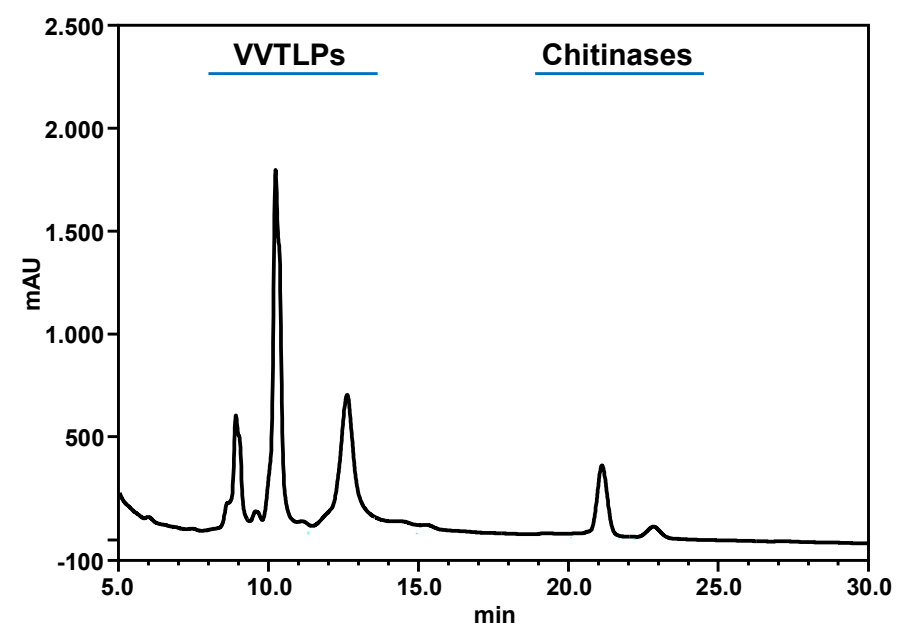

(c)

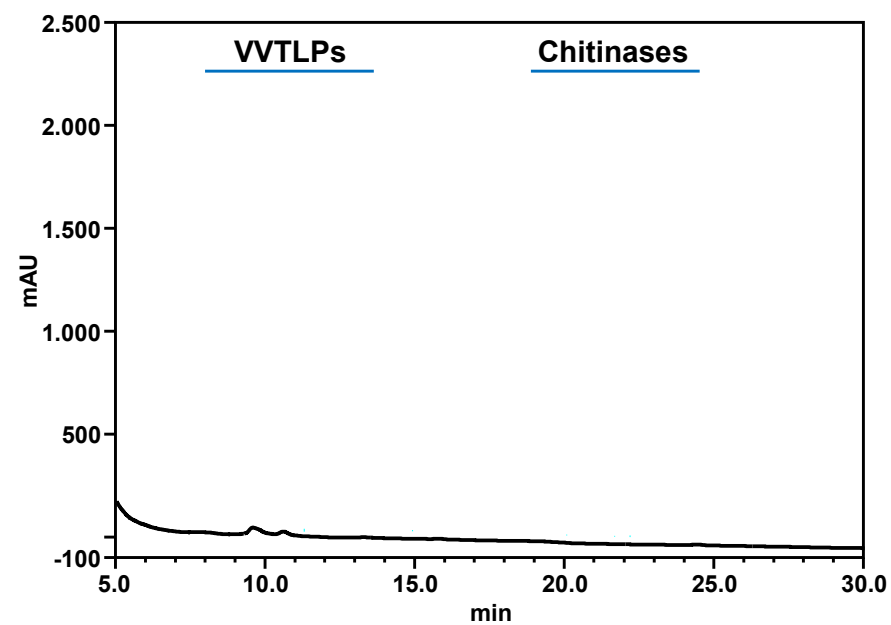

(b)

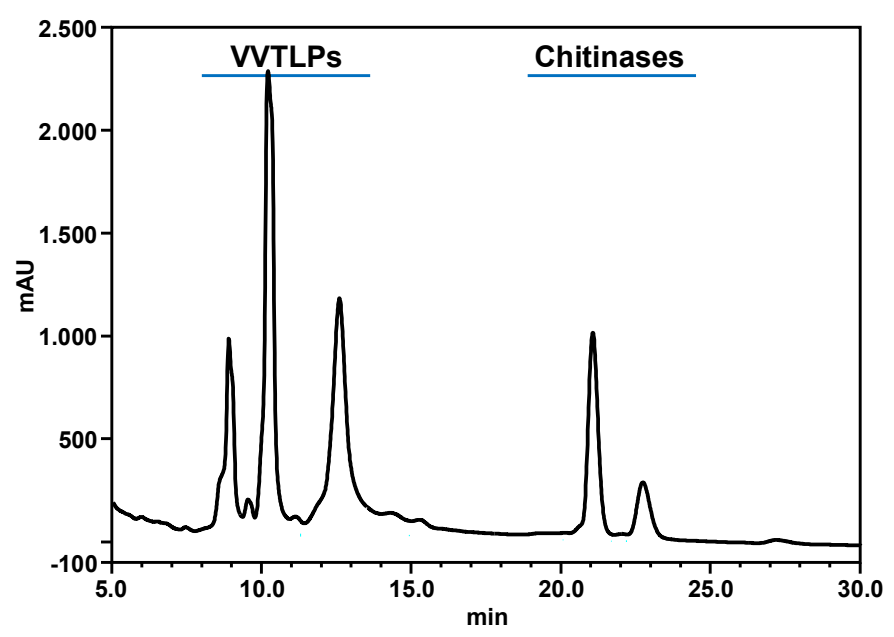

(d)

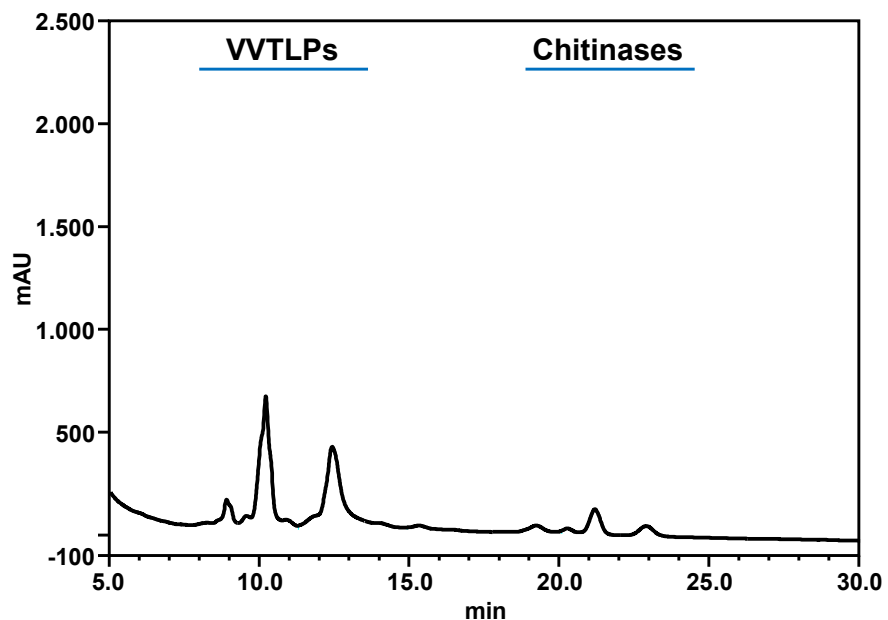

Figure 4. Cont. 
(e)

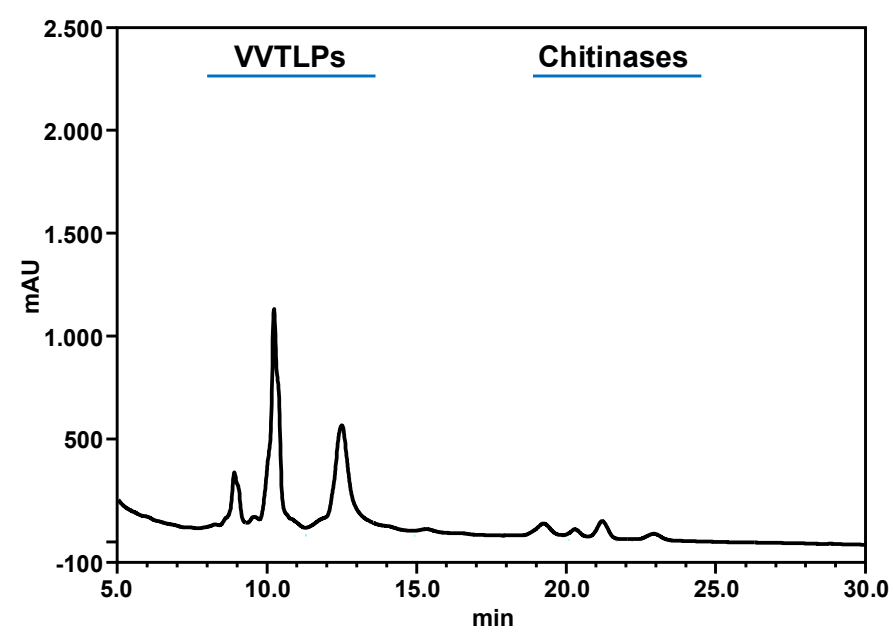

$(\mathbf{f})$

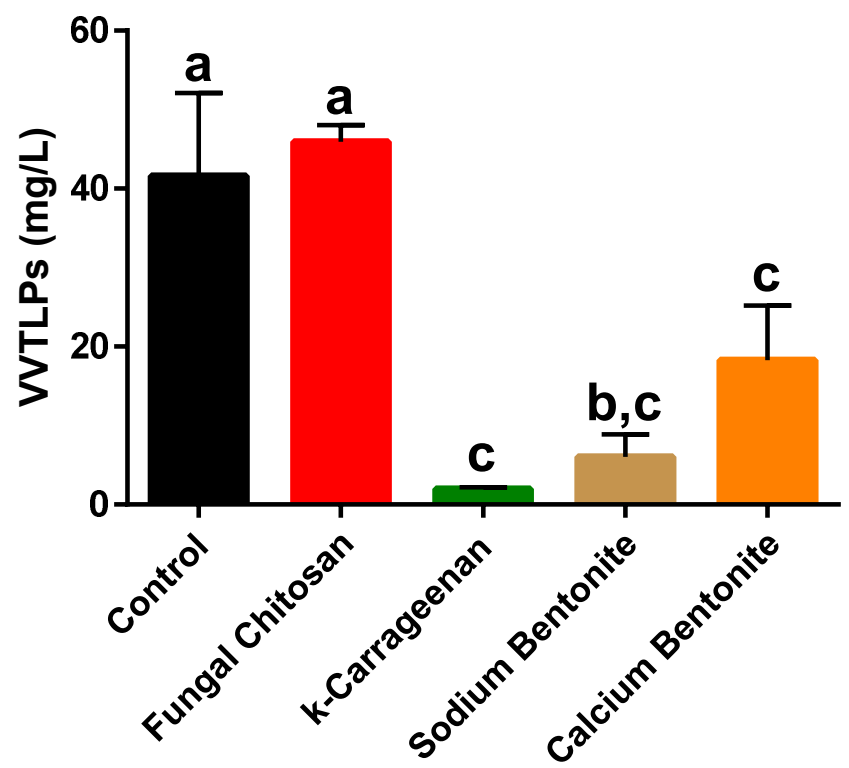

(g)

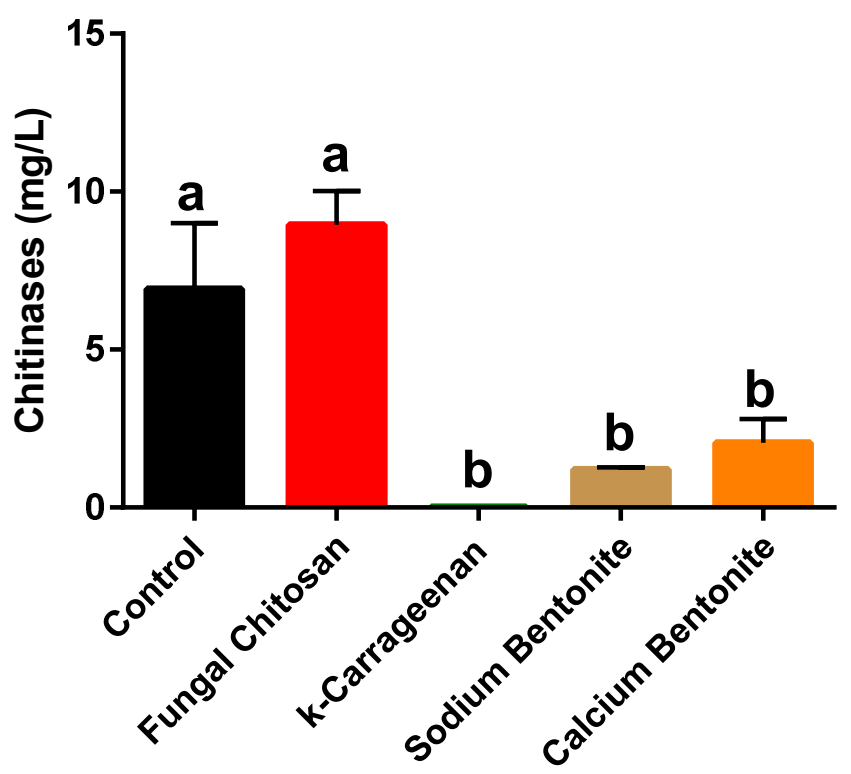

Figure 4. Reversed-phase HPLC results for the wine obtained without pre-fermentative skin maceration (-PFSM) and the impact of the different products applied for its protein stabilisation. (a) control wine without any additive; (b) after application of fungal chitosan at $100 \mathrm{~g} / \mathrm{hL}$; (c) after application of k-carrageenan at $100 \mathrm{~g} / \mathrm{hL}$; (d) after application of sodium bentonite at $120 \mathrm{~g} / \mathrm{hL}$; (e) after application of calcium bentonite at $120 \mathrm{~g} / \mathrm{hL}$. All chromatograms were obtained by analysis of a $5 \mathrm{mg} / \mathrm{mL}$ solution of the high molecular weight material (HMWM) after removal of the low molecular weight material by addition of $6 \mathrm{M}$ urea and repeated ultrafiltration through a $10 \mathrm{kDa}$ cut-off membrane, (f) Vitis vinifera thaumatin-like proteins (VVTLPs) concentration after application of fungal chitosan (100 g/hL), k-carrageenan (100 g/hL), sodium bentonite $(120 \mathrm{~g} / \mathrm{hL})$, and calcium bentonite $(120 \mathrm{~g} / \mathrm{hL},(\mathrm{g})$ chitinases concentration after application of fungal chitosan $(100 \mathrm{~g} / \mathrm{hL})$, k-carrageenan $(100 \mathrm{~g} / \mathrm{hL})$, sodium bentonite $(120 \mathrm{~g} / \mathrm{hL})$, and calcium bentonite $(120 \mathrm{~g} / \mathrm{hL})$. The columns values with the same letter are not statistically significant (Tukey $p<0.05$ ). 
(a)

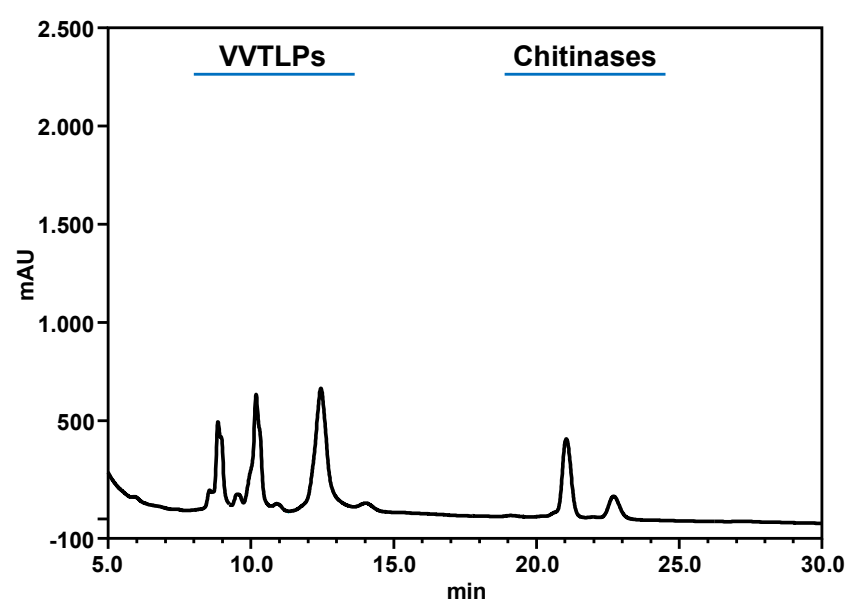

(c)

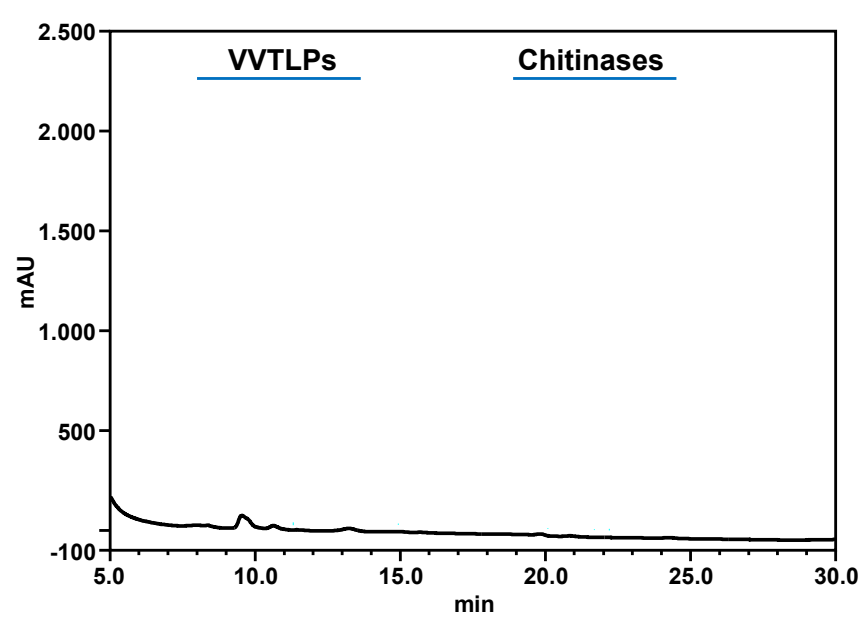

(b)

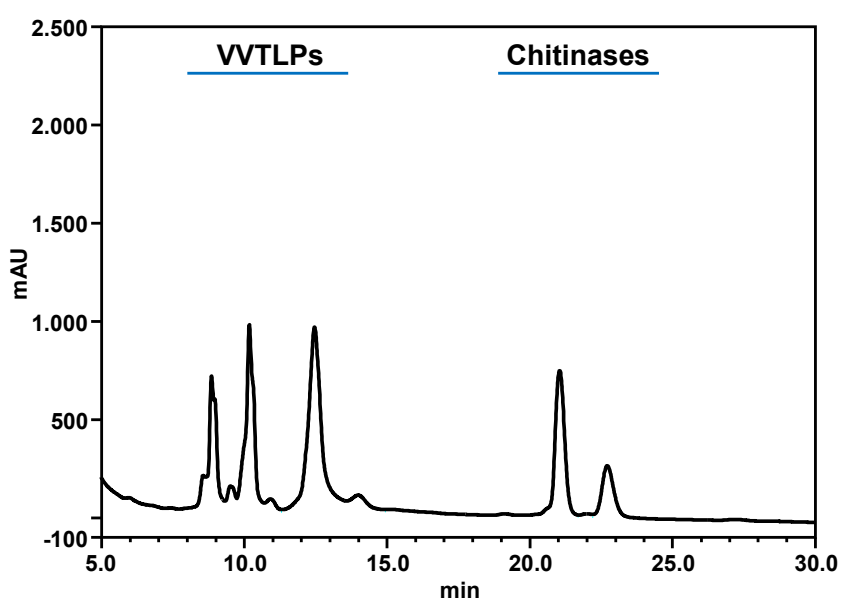

(d)

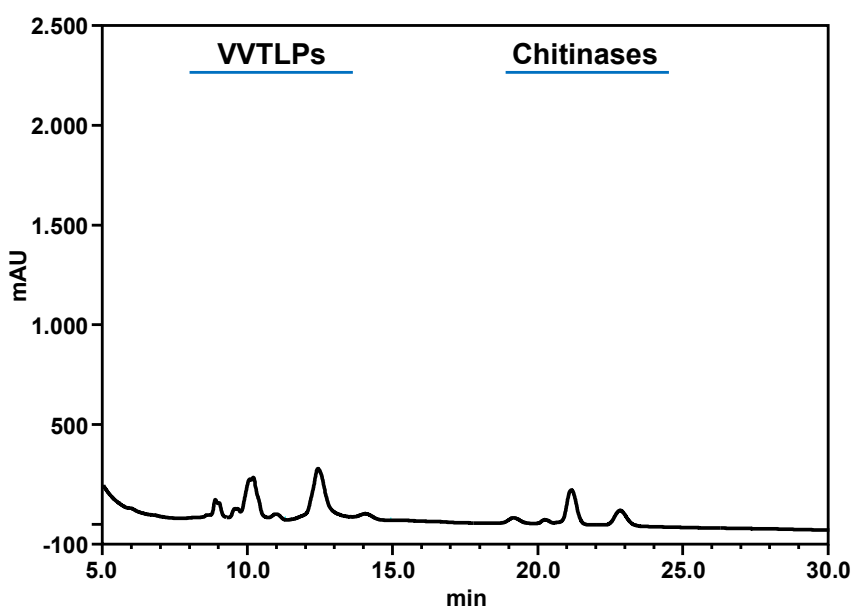

(e)

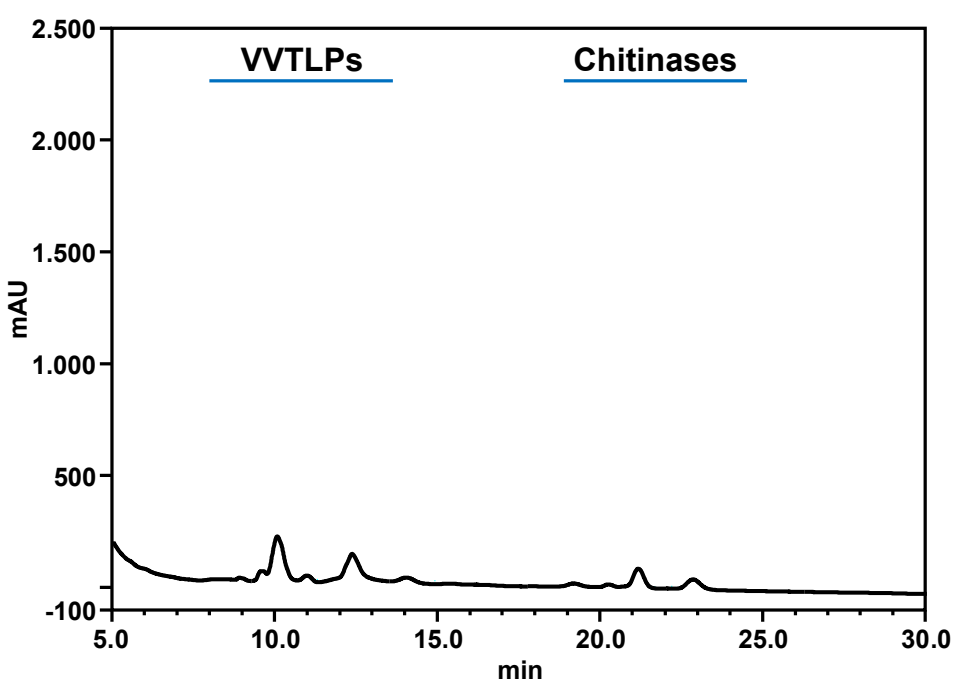

Figure 5. Cont. 
(f)

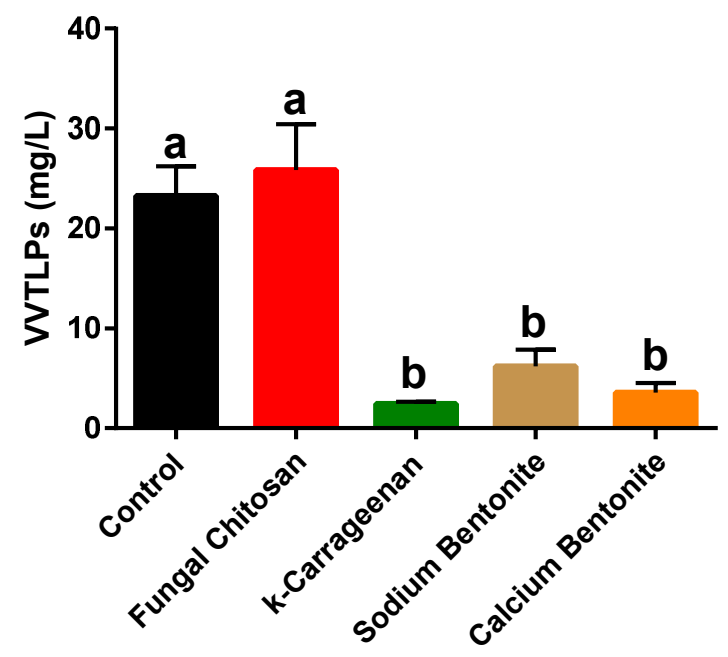

(g)

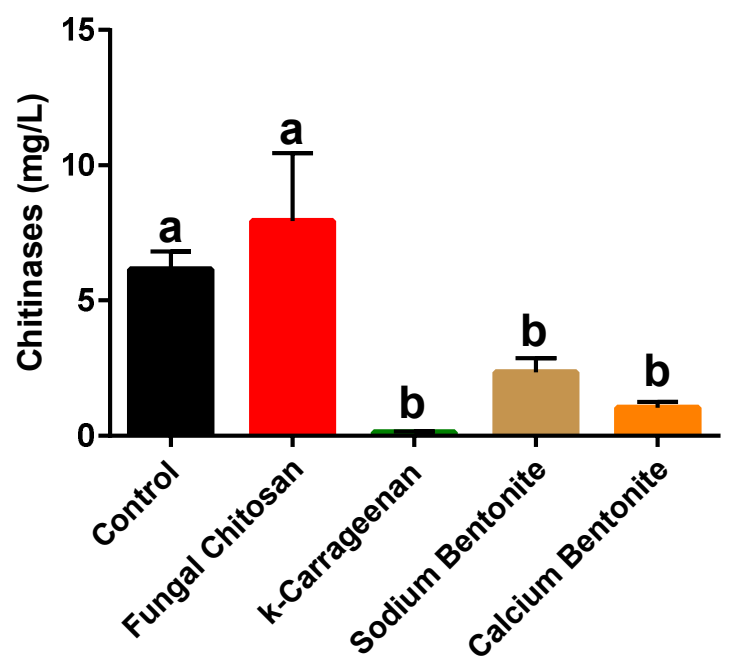

Figure 5. Reversed-phase HPLC results for the wine obtained with pre-fermentative skin maceration (+PFSM) and the impact of the different products applied for its protein stabilisation. (a) control wine without any additive; (b) after application of fungal chitosan at $100 \mathrm{~g} / \mathrm{hL}$; (c) after application of k-carrageenan at $100 \mathrm{~g} / \mathrm{hL}$; (d) after application of sodium bentonite at $120 \mathrm{~g} / \mathrm{hL}$; (e) after application of calcium bentonite at $120 \mathrm{~g} / \mathrm{hL}$. All chromatograms were obtained by analysis of a $5 \mathrm{mg} / \mathrm{mL}$ solution of the HMWM after removal of the low molecular weight material by addition of $6 \mathrm{M}$ urea and repeated ultrafiltration through a $10 \mathrm{kDa}$ cut-off membrane, (f) VVTLPs concentration after application of fungal chitosan $(100 \mathrm{~g} / \mathrm{hL})$, k-carrageenan $(100 \mathrm{~g} / \mathrm{hL})$, sodium bentonite $(120 \mathrm{~g} / \mathrm{hL})$, and calcium bentonite $(120 \mathrm{~g} / \mathrm{hL},(\mathrm{g}) \mathrm{chitinases}$ concentration after application of fungal chitosan $(100 \mathrm{~g} / \mathrm{hL}), \mathrm{k}$-carrageenan $(100 \mathrm{~g} / \mathrm{hL})$, sodium bentonite $(120 \mathrm{~g} / \mathrm{hL})$, and calcium bentonite $(120 \mathrm{~g} / \mathrm{hL})$. The columns values with the same letter are not statistically significant (Tukey $p<0.05)$.

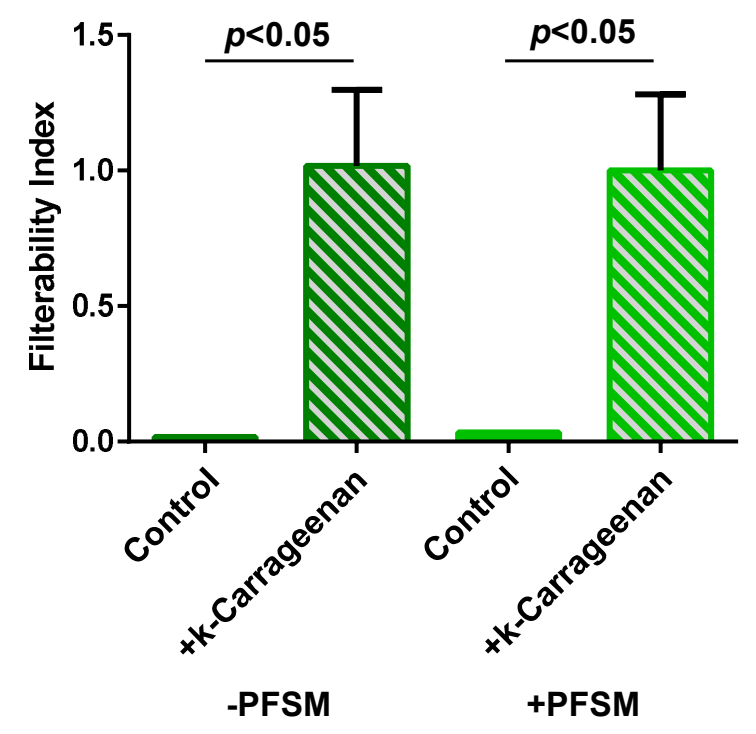

Figure 6. Effect of k-carrageenan addition to the Albariño white wines obtained without prefermentative skin maceration (-PFSM) and with pre-fermentative skin maceration (+PFSM).

3.4. Effect of the Skin Contact on the Albariño White Wine Phenolic Composition and Chromatic Characteristics, and Effect of the Addition of Fungal Chitosan, $k$-Carrageenan and Bentonite

In order to study the effect of the white wine obtained without pre-fermentative skin maceration (-PFSM) and with pre-fermentative skin maceration (+PFSM) in the phenolic composition of the wines and its possible relation to the total protein content, the phenolic 
composition of wines was determined using a colourimetric method and the individual phenolic compounds were analysed by RP-HPLC [58-60]. The chromatic characteristics were determined according to the CIELa* $\mathrm{b}^{*}$ method [56]. As can be observed in Table 2, + PFSM wine presented a significantly higher amount of total phenols, flavonoid phenols, and non-flavonoid phenols when compared to the -PFSM wine. In line with the highest extraction of phenolic compounds observed for the +PFSM wine, this wine presented a significantly lower lightness $\left(L^{*}\right)$ and higher yellow colour $\left(b^{*}\right.$ value) when compared with the -PFSM wine (Table 2). Table 3 presents the individual phenolic compounds for both wines and in Figure 7 is presented the volcano plot showing the representation of the log of the probability obtained by the t-test for each phenolic compound in function of the fold change in the individual and total phenolics concentration determined by HPLC. As can be observed in Table 3 and Figure 7, the +PFSM wine showed a significant increase in the total phenolics extracted (an increase of 29\%). The main phenolic compounds whose concentration increased by at least double were p-coumaric acid, catechin, the ethyl ester of p-coumaric acid, and ferulic acid. In this work, we only determined the monomeric flavonols, showing a significant increase in the catechin levels by maceration, probably resulting from the increased extraction from skins and seeds [77]. It is expected that an increase in condensed tannins will also occur; nevertheless, their levels were not determined by this method. Therefore, the lower amount of protein present in the final + PFSM wine is probably related to the higher levels of phenolic compounds in this wine.

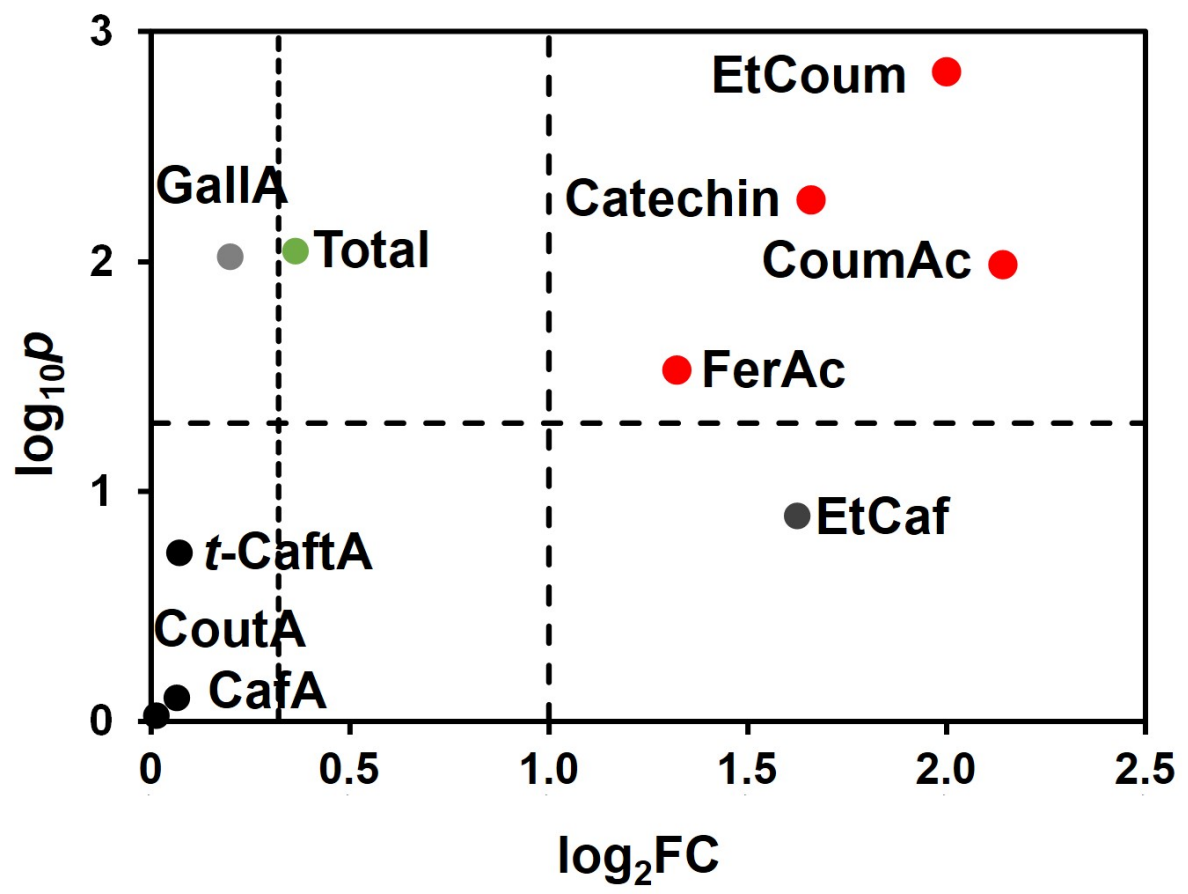

Figure 7. Volcano plot representing the statistical significance ( $\mathrm{p}$-values) on the Student $\mathrm{t}$-test and fold change (FC) for the phenolic content of Albariño white wine produced without pre-fermentative skin maceration (-PFSM) versus wine produced with pre-fermentative skin maceration (+PFSM). GallA-Gallic acid, t-CaftA—trans-Caftaric acid, CoutA-Coutaric acid, CoumAc-p-Coumaric acid, FerAc-Ferulic acid, CafA-Caffeic acid, EtCoum-Ethyl ester of p-coumarate, EtCaf-Ethyl ester of caffeate, Total-Total phenolic composition. 


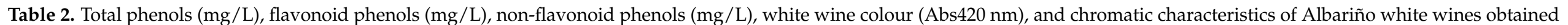

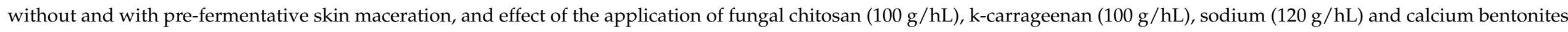
$(120 \mathrm{~g} / \mathrm{hL})$.

\begin{tabular}{|c|c|c|c|c|c|c|c|c|}
\hline & Total Phenols & Flavonoid Phenols & Non-Flavonoid Phenols & Abs $420 \mathrm{~nm}$ & $\mathbf{L}^{*}$ & $a^{*}$ & $\mathbf{b}^{*}$ & $\Delta \mathrm{E}^{*}$ \\
\hline \multicolumn{9}{|c|}{ Without pre-fermentative skin contact } \\
\hline Control & $39 \pm 1$ & $22 \pm 2^{a}$ & $17 \pm 1^{a}$ & $0.079 \pm 0.006^{\mathrm{a}}$ & $98.2 \pm 0.5^{a}$ & $0.14 \pm 0.08^{a}$ & $4.89 \pm 0.08$ & \\
\hline Fungal Chitosan & $35 \pm 0$ & $21 \pm 0^{\mathrm{a}, \mathrm{c}}$ & $15 \pm 1^{\mathrm{a}}$ & $0.076 \pm 0.014^{\mathrm{a}, \mathrm{b}}$ & $99.1 \pm 0.4^{\mathrm{a}, \mathrm{b}}$ & $0.12 \pm 0.08^{\mathrm{a}}$ & $3.84 \pm 0.96$ & $1.43 \pm 1.13$ \\
\hline k-Carrageenan & $38 \pm 1$ & $22 \pm 0^{a}$ & $16 \pm 0^{a}$ & $0.079 \pm 0.002^{\mathrm{a}}$ & $98.1 \pm 0.2^{\mathrm{a}}$ & $0.16 \pm 0.07^{\mathrm{a}}$ & $4.78 \pm 0.03$ & $0.13 \pm 0.07$ \\
\hline Sodium Bentonite & $38 \pm 0$ & $17 \pm 1 \mathrm{~b}, \mathrm{c}$ & $21 \pm 0^{b}$ & $0.075 \pm 0.002^{\mathrm{a}, \mathrm{b}}$ & $99.3 \pm 0.4^{\mathrm{a}, \mathrm{b}}$ & $-0.40 \pm 0.04^{b}$ & $4.00 \pm 0.28$ & $1.62 \pm 0.84$ \\
\hline Calcium Bentonite & $39 \pm 2$ & $24 \pm 1^{a}$ & $15 \pm 1^{a}$ & $0.048 \pm 0.003^{b}$ & $99.9 \pm 0.1^{\mathrm{b}}$ & $-0.46 \pm 0.02^{b}$ & $3.79 \pm 0.08$ & $1.07 \pm 0.30$ \\
\hline ANOVA & 0.0752 & 0.0157 & 0.0037 & 0.0279 & 0.0152 & 0.0003 & 0.1450 & 0.3059 \\
\hline \multicolumn{9}{|c|}{ With pre-fermentative skin contact } \\
\hline Control & $59 \pm 0^{\mathrm{a}}$ & $32 \pm 0^{a}$ & $28 \pm 0^{a}$ & $0.117 \pm 0.008^{\mathrm{a}}$ & $97.8 \pm 0.5$ & $0.77 \pm 0.02$ & $6.78 \pm 0.17^{\mathrm{a}}$ & \\
\hline Fungal Chitosan & $52 \pm 0 \mathrm{~b}, \mathrm{c}$ & $33 \pm 1^{a}$ & $19 \pm 1^{b}$ & $0.084 \pm 0.008^{b}$ & $98.1 \pm 0.2$ & $0.70 \pm 0.12$ & $5.32 \pm 0.49^{b}$ & $1.52 \pm 0.31$ \\
\hline k-Carrageenan & $54 \pm 0^{\mathrm{b}}$ & $33 \pm 1^{\mathrm{a}}$ & $21 \pm 0^{b, c}$ & $0.116 \pm 0.002^{\mathrm{a}}$ & $97.6 \pm 0.1$ & $0.81 \pm 0.04$ & $6.68 \pm 0.11^{\mathrm{a}}$ & $0.19 \pm 0.11$ \\
\hline Sodium Bentonite & $48 \pm 0^{\mathrm{c}}$ & $26 \pm 1 \mathrm{~b}, \mathrm{c}$ & $22 \pm 0^{\mathrm{c}}$ & $0.107 \pm 0.010^{\mathrm{a}, \mathrm{b}}$ & $97.3 \pm 0.7$ & $1.03 \pm 0.14$ & $6.49 \pm 0.15^{\mathrm{a}}$ & $0.74 \pm 0.48$ \\
\hline Calcium Bentonite & $52 \pm 0 \mathrm{~b}, \mathrm{c}$ & $29 \pm 1^{a, c}$ & $22 \pm 0^{\mathrm{c}}$ & $0.102 \pm 0.005^{\mathrm{a}, \mathrm{b}}$ & $97.6 \pm 0.2$ & $0.99 \pm 0.07$ & $6.42 \pm 0.23^{\mathrm{a}}$ & $0.59 \pm 0.27$ \\
\hline ANOVA & 0.0001 & 0.0023 & 0.0002 & 0.0280 & 0.4670 & 0.0534 & 0.0143 & 0.0575 \\
\hline$t$-test & 0.0016 & 0.0206 & 0.0051 & 0.0329 & 0.508 & 0.0085 & 0.0049 & \\
\hline
\end{tabular}

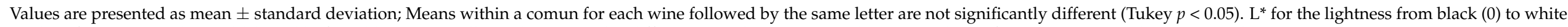
$(100)$, $\mathrm{a}^{*}$ from green $(-)$ to red $(+)$, and $\mathrm{b}^{*}$ from blue $(-)$ to yellow $(+), \Delta \mathrm{E}^{*}$ - Color difference in relation to control wine. Analysis of variance (ANOVA). $t$-test-Student's $t$-test. 


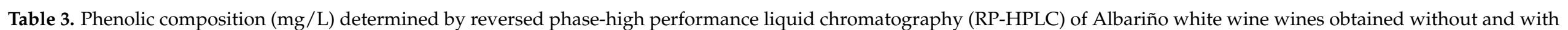
pre-fermentative skin maceration and effect of the application of fungal chitosan (100 g/hL), k-carrageenan (100 g/hL), sodium (120 g/hL) and calcium bentonites (120 g/hL).

\begin{tabular}{|c|c|c|c|c|c|c|c|c|c|c|}
\hline & Gallic Acid & Catechin & $t$-Caftaric Acid & Coutaric Acid & Caffeic Acid & $\begin{array}{c}p \text {-Coumaric } \\
\text { Acid }\end{array}$ & Ferulic Acid & $\begin{array}{c}\text { Ethyl Ester of } \\
\text { Caffeate }\end{array}$ & $\begin{array}{l}\text { Ethyl Ester of } \\
p \text {-Coumarate }\end{array}$ & Total \\
\hline \multicolumn{11}{|c|}{ Without pre-fermentative skin maceration } \\
\hline Control & $50.0 \pm 0.9$ & $7.06 \pm 1.48$ & $23.8 \pm 0.3$ & $21.7 \pm 1.6$ & $6.48 \pm 0.74$ & $1.84 \pm 0.80$ & $0.06 \pm 0.01$ & $0.12 \pm 0.14$ & $0.12 \pm 0.00$ & $111.4 \pm 3.5^{\mathrm{a}}$ \\
\hline Fungal Chitosan & $46.0 \pm 0.1$ & $6.78 \pm 0.34$ & $23.6 \pm 0.6$ & $15.5 \pm 1.8$ & $5.89 \pm 0.09$ & $1.07 \pm 0.23$ & $0.04 \pm 0.02$ & $0.03 \pm 0.00$ & $0.10 \pm 0.02$ & $99.1 \pm 1.1^{b}$ \\
\hline k-Carrageenan & $48.3 \pm 1.6$ & $6.06 \pm 0.06$ & $23.3 \pm 0.3$ & $16.2 \pm 2.8$ & $6.14 \pm 0.13$ & $1.66 \pm 0.22$ & $0.05 \pm 0.01$ & $0.06 \pm 0.04$ & $0.08 \pm 0.06$ & $102.0 \pm 0.7^{b}$ \\
\hline Sodium Bentonite & $49.7 \pm 0.2$ & $5.58 \pm 0.61$ & $23.7 \pm 1.1$ & $14.9 \pm 0.1$ & $6.53 \pm 0.05$ & $1.33 \pm 0.04$ & $0.04 \pm 0.01$ & $0.03 \pm 0.00$ & $0.05 \pm 0.04$ & $101.9 \pm 0.6^{b}$ \\
\hline Calcium Bentonite & $52.7 \pm 6.9$ & $3.70 \pm 0.99$ & $22 . .9 \pm 0.5$ & $15.6 \pm 0.4$ & $6.14 \pm 0.41$ & $1.19 \pm 0.23$ & $0.03 \pm 0.01$ & $0.06 \pm 0.06$ & $0.06 \pm 0.01$ & $102.5 \pm 2.6^{\mathrm{b}}$ \\
\hline \multicolumn{11}{|c|}{ With pre-fermentative skin maceration } \\
\hline Control & $57.4 \pm 0.5^{\mathrm{a}}$ & $22.3 \pm 0.6$ & $25.0 \pm 0.8$ & $22.7 \pm 4.4$ & $6.54 \pm 0.80$ & $8.12 \pm 0.43$ & $0.15 \pm 0.02$ & $0.37 \pm 0.01$ & $0.48 \pm 0.02$ & $143.3 \pm 2.5^{\mathrm{a}}$ \\
\hline Fungal Chitosan & $31.5 \pm 4.9^{b}$ & $22.4 \pm 0.2$ & $26.0 \pm 3.5$ & $20.4 \pm 5.6$ & $6.11 \pm 0.44$ & $5.29 \pm 1.03$ & $0.06 \pm 0.01$ & $0.32 \pm 0.01$ & $0.44 \pm 0.07$ & $112.9 \pm 1.3^{c}$ \\
\hline k-Carrageenan & $50.5 \pm 4.6^{\mathrm{a}}$ & $22.7 \pm 1.9$ & $25.9 \pm 3.2$ & $19.7 \pm 0.2$ & $5.86 \pm 0.15$ & $5.48 \pm 3.58$ & $0.07 \pm 0.06$ & $0.36 \pm 0.07$ & $0.47 \pm 0.06$ & $129.6 \pm 3.4^{b, c}$ \\
\hline Sodium Bentonite & $47.1 \pm 2.1^{\mathrm{a}}$ & $20.7 \pm 0.2$ & $25.1 \pm 0.5$ & $18.5 \pm 2.1$ & $5.83 \pm 0.08$ & $6.88 \pm 0.43$ & $0.13 \pm 0.08$ & $0.36 \pm 0.02$ & $0.13 \pm 0.12$ & $124.7 \pm 0.4^{b}$ \\
\hline Calcium Bentonite & $35.3 \pm 0.9^{b}$ & $20.4 \pm 0.6$ & $24.4 \pm 0.6$ & $19.6 \pm 1.1$ & $5.70 \pm 0.03$ & $4.93 \pm 0.89$ & $0.13 \pm 0.07$ & $0.29 \pm 0.09$ & $0.40 \pm 0.31$ & $118.4 \pm 5.3^{b}$ \\
\hline ANOVA & 0.0021 & 0.1639 & 0.1883 & 0.7753 & 0.3888 & 0.4206 & 0.4655 & 0.5520 & 0.2718 & 0.0012 \\
\hline
\end{tabular}

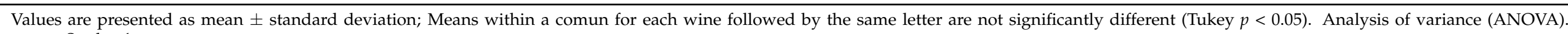
$t$-test-Student's -test. 
Table 3 also shows the phenolic composition of the two white wines after application of the fungal chitosan, k-carrageenan, sodium, and calcium bentonite. As can be observed, the application of the different fining agents resulted in a significant but small decrease in the total phenols of the wines, the decrease being generally smaller for the +PFSM wine (from 11\% for the fungal chitosan to $8 \%$ for the calcium bentonite and k-carrageenan) than -PFSM (from 23\% for fungal chitosan and calcium bentonite to $10 \%$ for k-carrageenan). Again, depending on the wine matrix, the effect of the application of the different fining agents was different; nevertheless, for the application of fungal chitosan, a significant decrease in the $b^{*}$ values and an increase in the $L^{*}$ values were observed. The application of sodium and calcium bentonites did not affect the $L^{*}$ and $b^{*}$ values for the +PFSM wine, although for the -PFSM wine a significant decrease in the $L^{*}$ and $a^{*}$ values was observed. In general, the impact of these fining agents on the chromatic characteristics of both wines was small.

3.5. Effect of the Skin Contact on the Albariño Wine Polysaccharides Composition and Effect of the Addition of Fungal Chitosan, $k$-Carrageenan and Bentonite

Table 4 shows the total polysaccharides content of both wines and their sugar composition. As can be observed the white wine obtained with pre-fermentative skin maceration increased significantly the total polysaccharide content of the wines ( $28 \%$ increase). Both wines contained significant amounts of mannose, which was the main sugar with a relative abundance of 28 to $43 \%$ by weight of the total sugars present in +PFSM and -PFSM wines, respectively. This is probably derived from the mannoproteins released into the wines by Saccharomyces yeast during fermentation [77]. Nonetheless, the amount of mannose present in both wines was not significantly different (Table 4). Galacturonic acid was the second most abundant sugar accounting for nearly $22 \%$ of the total polysaccharides of both wines. Its amount was significantly higher for +PFSM wine (28\% increase; Table 4 ). Galacturonic acid and rhamnose are probably derived from the rhamnogalacturonan I and rhamnogalacturonan II pectic polysaccharides originating from grapes [78,79]. As observed for galacturonic acid residues, the level of rhamnose residues present in wine also increased significantly with the pre-fermentative skin maceration winemaking technology (103\% increase; Table 4), with the rhamnose residues accounting for 5 and $8 \%$ of the total polysaccharides extracted for +PFSM and -PFSM wines, respectively. Galactose residues account for a significant amount of the polysaccharides extracted with both winemaking techniques, accounting for nearly $14 \%$ of the total polysaccharides. Galactose residues along with arabinose residues are derived from the type I and type II arabinogalactans from grapes [41]. The arabinose residues extracted increased significantly for the wines obtained with the pre-fermentative skin maceration (115\% increase) representing $4 \%$ to $7 \%$ of the wine polysaccharides obtained without and with pre-fermentative skin maceration, respectively. The most significant changes observed in the wine polysaccharide composition were related to the significant increase in the glucuronic acid residues (181\% increase) and the appearance of a significant amount of xylose residues in the +PFSM wine; xylose was not detected in the -PFSM wine. Glucuronic acid residues are known to be constituents of grape-derived wine type II arabinogalactans where they can be present in the arabinose side chains of arabinogalactans. This increase can be due to the extraction of more glucuronic acid-containing type II arabinogalactans [79] when the wines were obtained with pre-fermentative skin maceration. Xylose residues are probably derived from grape skin xylans $[80,81]$. Therefore, these results show that the pre-fermentative skin maceration process can increase the total polysaccharides present in wine derived from the grape skins. 


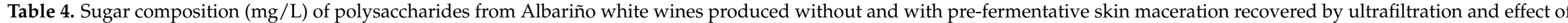
the application of fungal chitosan $(100 \mathrm{~g} / \mathrm{hL})$, k-carrageenan $(100 \mathrm{~g} / \mathrm{hL})$, sodium $(120 \mathrm{~g} / \mathrm{hL})$ and calcium bentonites $(120 \mathrm{~g} / \mathrm{hL})$.

\begin{tabular}{|c|c|c|c|c|c|c|c|c|c|c|c|}
\hline & Fuc & Rha & Ara & GlcN & Gal & Glc & Xyl & Man & GalA & GlcA & Total \\
\hline \multicolumn{12}{|c|}{ Without pre-fermentative skin contact } \\
\hline Control & $0.25 \pm 0.03^{\mathrm{a}}$ & $2.79 \pm 0.15^{\mathrm{a}}$ & $2.46 \pm 0.10^{\mathrm{a}}$ & $0.91 \pm 0.17^{\mathrm{a}}$ & $9.17 \pm 0.55^{\mathrm{a}}$ & $2.04 \pm 0.06^{\mathrm{a}}$ & n.d. & $27.8 \pm 0.1^{\mathrm{a}}$ & $12.4 \pm 0.2^{\mathrm{a}}$ & $3.73 \pm 0.33^{\mathrm{a}}$ & $61.6 \pm 1.0^{\mathrm{a}}$ \\
\hline Fungal Chitosan & n.d. ${ }^{c}$ & $0.59 \pm 0.13^{c}$ & $1.00 \pm 0.06^{b}$ & $0.66 \pm 0.17^{a, b}$ & $5.25 \pm 0.80^{\mathrm{b}}$ & $1.87 \pm 0.44^{\mathrm{a}, \mathrm{c}}$ & n.d. & $13.4 \pm 1.6^{\mathrm{b}}$ & $1.28 \pm 0.53^{b}$ & $0.90 \pm 0.01^{\mathrm{b}}$ & $29.0 \pm 1.0^{c}$ \\
\hline k-Carrageenan & $0.25 \pm 0.02^{\mathrm{a}}$ & $2.79 \pm 0.15^{\mathrm{a}}$ & $2.72 \pm 0.33^{\mathrm{a}}$ & $1.06 \pm 0.09^{\mathrm{a}}$ & $13.3 \pm 1.2^{c}$ & $3.31 \pm 0.39^{b}$ & n.d. & $24.8 \pm 1.9^{\mathrm{a}}$ & $10.4 \pm 2.3^{\mathrm{a}}$ & $3.93 \pm 0.12^{\mathrm{a}}$ & $65.6 \pm 2.2^{\mathrm{a}}$ \\
\hline Sodium Bentonite & $0.11 \pm 0.01^{\mathrm{b}}$ & $1.33 \pm 0.11^{b}$ & $1.38 \pm 0.21^{b}$ & $0.35 \pm 0.05^{\mathrm{b}}$ & $5.40 \pm 0.85^{\mathrm{b}}$ & $0.89 \pm 0.21^{\mathrm{c}}$ & n.d. & $11.9 \pm 1.5^{b}$ & $2.18 \pm 0.91^{b}$ & $1.86 \pm 0.06^{c}$ & $25.4 \pm 3.8^{c}$ \\
\hline Calcium Bentonite & $0.17 \pm 0.04^{\mathrm{a}, \mathrm{b}}$ & $2.36 \pm 0.18^{\mathrm{a}}$ & $2.64 \pm 0.19^{\mathrm{a}}$ & $0.70 \pm 0.06^{\mathrm{a}, \mathrm{b}}$ & $10.4 \pm 0.3^{a, c}$ & $1.52 \pm 0.13^{\mathrm{a}, \mathrm{c}}$ & n.d. & $23.5 \pm 1.3^{\mathrm{a}}$ & $4.83 \pm 0.11^{\mathrm{b}}$ & $3.50 \pm 0.25^{\mathrm{a}}$ & $49.6 \pm 2.0^{b}$ \\
\hline ANOVA & 0.0007 & $<0.0001$ & 0.0010 & 0.0129 & 0.0007 & 0.0031 & - & 0.0003 & 0.0006 & $<0.0001$ & $<0.0001$ \\
\hline \multicolumn{12}{|c|}{ With pre-fermentative skin contact } \\
\hline Control & $0.36 \pm 0.02^{\mathrm{a}}$ & $5.68 \pm 0.01^{\mathrm{a}}$ & $5.30 \pm 0.15^{b}$ & $0.87 \pm 0.06^{\mathrm{a}}$ & $11.7 \pm 0.5^{\mathrm{a}}$ & $2.62 \pm 0.55^{\mathrm{a}}$ & $2.75 \pm 0.07^{\mathrm{a}}$ & $23.2 \pm 1.4^{\mathrm{a}}$ & $15.9 \pm 1.0^{\mathrm{a}}$ & $10.5 \pm 1.5^{\mathrm{a}}$ & $78.8 \pm 2.2^{\mathrm{a}}$ \\
\hline Fungal Chitosan & $0.02 \pm 0.01^{c}$ & $1.50 \pm 0.02^{b}$ & $2.25 \pm 0.24^{c}$ & $0.44 \pm 0.07^{\mathrm{b}}$ & $5.57 \pm 0.84^{b}$ & $1.97 \pm 0.15^{\mathrm{a}}$ & $0.97 \pm 0.16^{b}$ & $9.79 \pm 1.91^{b}$ & $3.02 \pm 1.07^{b}$ & $1.86 \pm 0.22^{b}$ & $27.4 \pm 2.6^{b}$ \\
\hline k-Carrageenan & $0.38 \pm 0.02^{a}$ & $5.08 \pm 0.25^{\mathrm{a}}$ & $6.34 \pm 0.31^{a}$ & $0.84 \pm 0.02^{\mathrm{a}}$ & $19.4 \pm 0.3^{c}$ & $4.93 \pm 1.35^{b}$ & $3.92 \pm 0.48^{c}$ & $28.4 \pm 1.0^{c}$ & $16.0 \pm 3.0^{\mathrm{a}}$ & $10.2 \pm 1.5^{\mathrm{a}}$ & $95.8 \pm 1.3^{c}$ \\
\hline Sodium Bentonite & $0.27 \pm 0.02^{b}$ & $4.39 \pm 0.29^{a}$ & $4.44 \pm 0.06^{b}$ & $0.46 \pm 0.02^{b}$ & $10.8 \pm 0.5^{\mathrm{a}}$ & $1.55 \pm 0.05^{\mathrm{a}}$ & $1.57 \pm 0.08^{b}$ & $15.3 \pm 0.4^{\mathrm{d}}$ & $12.3 \pm 0.2^{\mathrm{a}}$ & $6.56 \pm 0.42^{a, c}$ & $57.6 \pm 0.9^{d}$ \\
\hline Calcium Bentonite & $0.30 \pm 0.03^{\mathrm{a}, \mathrm{b}}$ & $5.92 \pm 0.96^{\mathrm{a}}$ & $5.23 \pm 0.30^{\mathrm{b}}$ & $0.47 \pm 0.08^{b}$ & $13.5 \pm 0.04^{\mathrm{a}}$ & $1.86 \pm 0.31^{\mathrm{a}}$ & $2.20 \pm 0.05^{\mathrm{a}}$ & $18.9 \pm 0.1^{\mathrm{a}, \mathrm{d}}$ & $11.7 \pm 1.1^{\mathrm{a}}$ & $5.88 \pm 0.70^{b, c}$ & $65.9 \pm 1.9^{\mathrm{e}}$ \\
\hline ANOVA & $<0.0001$ & 0.0011 & $<0.0001$ & 0.0010 & $<0.0001$ & 0.0073 & 0.0004 & $<0.0001$ & 0.0021 & 0.0018 & $<0.0001$ \\
\hline$t$-test & 0.0497 & 0.0014 & 0.0020 & 0.7834 & 0.0406 & 0.2764 & 0.0001 & 0.0435 & 0.0399 & 0.0248 & 0.0097 \\
\hline
\end{tabular}

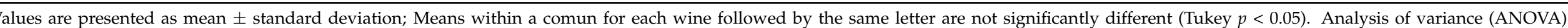

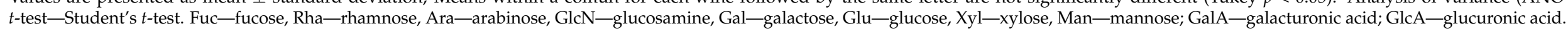


The addition of chitosan drastically decreased the polysaccharide content of the wines: $59 \%$ in the -PFSM wine and 65\% in +PFSM wine (Table 4). Although chitosan application has reduced the content of all polysaccharides, the sugars with a higher reduction were galacturonic acid and rhamnose, as well as glucuronic acid, showing that the biggest impact of chitosan was on the polysaccharides bearing potential negative charge due to the presence of these two uronic acids. Therefore, we hypothesised that their removal is due to the electrostatic interaction between the positively charged chitosan and the negatively charged polysaccharides, probably rhamnogalacturonan I and II and type II arabinogalactans as a decrease in the galactose and arabinose residues was also observed. This trend is observed for both wines, with and without pre-fermentative skin maceration. Yeast mannoproteins, grape arabinogalactan-proteins (AGP), and rhamnogalacturonan RG-II-carried negative charges in the wine $\mathrm{pH}$ range. The net charge density of yeast mannoproteins was shown to be related to their phosphorus content and absolute charge densities of AGP and RG-II were related to the dissociation of the carboxylic functions of their uronic acids [82]. Sodium bentonite was the second treatment in reducing the levels of polysaccharides from both wines. In the -PFSM wine, sodium bentonite resulted in a decrease of $59 \%$ in the total polysaccharides, and for the +PFSM wine, the reduction was $27 \%$ (Table 4). For the - PFSM wine, the polysaccharide removal profile was similar to that observed for the fungal chitosan, but for the +PFSM wine, the main affected sugar residue was mannose, allowing us to infer that it is mainly removing wine mannoproteins. The impact of the application of calcium bentonite was lower than that observed for the application of sodium bentonite, nevertheless, its use also significantly reduced the total levels of polysaccharides in the final wines, being observed a reduction of $19 \%$ and $16 \%$ for the -PFSM and +PFSM wines (Table 4). k-Carrageenan application increased on average, although not significantly, the levels of polysaccharides present in the wine, being mainly observed a significant increase in the levels of galactose and glucose residues, showing that after application and filtration some polysaccharides from the k-carrageenan preparation used remained in the wine. As can be observed in Table 4, and in contrast to the other fining agents used, k-carrageenan was the only fining agent that did not affect significantly the levels of the remaining polysaccharides (Table 4). Of all the fining agents used, $\mathrm{k}$ carrageenan showed a higher specificity in the removal of the heat unstable proteins without impacting polysaccharide composition.

\section{Conclusions}

Pre-fermentative skin maceration increased the levels of phenolic compounds and polysaccharides extracted and reduced the amount of protein extracted, especially of the pathogenesis-related proteins, namely the Vitis vinifera thaumatin-like proteins and chitinases. Although the total protein and PRPs of the Albariño wine obtained by prefermentative skin maceration were lower, it showed a significantly higher protein instability. When the efficiency of sodium and calcium bentonite, fungal chitosan, and k-carrageenan for wine protein stabilisation were compared it was observed that k-carrageenan reduced the wine protein instability and the content of Vitis vinifera thaumatin-like proteins and chitinases and was effective for both wines. Sodium and calcium bentonites were also able to increase the wine protein stability but only for the wine obtained without prefermentative skin maceration. They were less efficient in decreasing the levels of Vitis vinifera thaumatin-like proteins and chitinases in both white wines when compared to k-carrageenan. Fungal chitosan was unable to heat stabilise the wines and did not change the levels of Vitis vinifera thaumatin-like proteins and chitinases. On the other hand, fungal chitosan decreased by $\sim 60 \%$ the levels of wine polysaccharides, the same being observed for sodium and calcium bentonite, although these two fining agents being less deleterious. k-Carrageenan did not decrease significantly the levels of polysaccharides present in both wines. The use of k-carrageenan decreased slightly the wine filterability, but at a level that does not affect its filterability in practical terms. Therefore, the use of $\mathrm{k}$-carrageenan for white wine protein stabilisation is a good approach as its impact on the 
macromolecular components is more specific, i.e., it significantly reduced the levels of the PRPs of wines without impacting the polysaccharide composition, with similar or even better efficiency than sodium bentonite. The use of skin maceration in the production of Albariño white wines showed a positive influence on the levels of polysaccharides and phenolic compounds and this can have a positive influence on the sensory characteristics of the final wines. Nevertheless, future work using sensory analysis is needed to access the impact of these changes on the quality of the final wines.

Author Contributions: Conceptualization, M.R., L.F.-R., F.C. and F.M.N.; methodology, M.R., F.C., F.M.N.; validation, M.R., L.F.-R., F.C. and F.M.N.; formal analysis, I.A., M.R., L.F.-R., F.C. and F.M.N.; investigation, I.A., M.R., R.V., E.C., J.S.; resources, F.C., F.M.N.; data curation, I.A., M.R., L.F.-R., F.C. and F.M.N.; writing-original draft preparation, I.A., M.R., L.F.-R., F.C. and F.M.N.; writingreview and editing, I.A., M.R., L.F.-R., R.V., E.C., J.S., F.C., F.M.N.; supervision, F.C., F.M.N.; funding acquisition, F.C., F.M.N. All authors have read and agreed to the published version of the manuscript.

Funding: This research was funded by Fundação para a Ciência Tecnologia (FCT-Portugal) to CQVR (UIDB/00616/2020 and UIDP/00616/2020) and by the European Regional Development Fund through NORTE 2020 (Programa Operacional Regional do Norte 2014/2020) to the projetc AgriFood XXI (NORTE-01-0145-FEDER-000041).

Acknowledgments: The authors acknowledge Bodegas la Caña, S.L. do Grupo Jorge Ordoñez Selections for performing the vinification process of the wines used in this study, Ceamsa, Spain, for supplying the k-carrageenan sample used in this study and SAI, Portugal, for performing the FTIR analysis.

Conflicts of Interest: The authors declare no conflict of interest.

\section{References}

1. Darias-Martín, J.J.; Rodríguez, O.; Díaz, E.; Lamuela-Raventós, R.M. Effect of skin contact on the antioxidant phenolics in white wine. Food Chem. 2000, 71, 483-487. [CrossRef]

2. Selli, S. Effect of skin contact on the aroma composition of the musts of Vitis vinifera L. cv. Muscat of Bornova and Narince grown in Turkey. Food Chem. 2003, 81, 341-347. [CrossRef]

3. Ramey, D.; Bertrand, A.; Ough, C.S.; Singleton, V.L.; Sanders, E. Effect of skin contact temperature on Chardonnay must and wine composition. Am. J. Enol. Vitic. 1986, 37, 99-106.

4. Selli, S.; Canbas, A.; Cabaroglu, T.; Erten, H.; Günata, Z. Aroma components of cv. Muscat of Bornova wines and influence of skin contact treatment. Food Chem. 2006, 94, 319-326. [CrossRef]

5. Tian, B.; Harrison, R.; Morton, J.; Jaspers, M. Influence of skin contact and different extractants on extraction of proteins and phenolic substances in Sauvignon Blanc grape skin. Aust. J. Grape Wine Res. 2020, 26, 180-186. [CrossRef]

6. Ough, C.S. Substances extracted during skin contact with white musts. I. General wine composition and quality changes with contact time. Am. J. Enol. Vitic. 1969, 20, 93-100.

7. Boulton, R. The general relationship between potassium, sodium and $\mathrm{pH}$ in grape juice and wine. Am. J. Enol. Vitic. 1980, 31, 182-186.

8. Sokolowsky, M.; Rosenberger, A.; Fischer, U. Sensory impact of skin contact on white wines characterized by descriptive analysis, time-intensity analysis and temporal dominance of sensations analysis. Food Qual. Prefer. 2015, 39, 285-297. [CrossRef]

9. Ferreira, R.B.; A Piçarra-Pereira, M.; Monteiro, S.; Loureiro, V.B.; Teixeira, A.R. The wine proteins. Trends Food Sci. Technol. 2001, 12, 230-239. [CrossRef]

10. Robinson, S.P.; Davies, C. Molecular biology of grape berry ripening. Aust. J. Grape Wine Res. 2000, 6, 175-188. [CrossRef]

11. Cosme, F.; Filipe-Ribeiro, L.; Nunes, F.M. Wine Stabilisation: An Overview of Defects and Treatments. In Chemistry and Biochemistry of Winemaking, Wine Stabilization and Aging [Working Title]; IntechOpen: London, UK, 2021.

12. Sauvage, F.-X.; Bach, B.; Moutounet, M.; Vernhet, A. Proteins in white wines: Thermo-sensitivity and differential adsorbtion by bentonite. Food Chem. 2010, 118, 26-34. [CrossRef]

13. Dambrouck, T.; Marchal, R.; Marchal-Delahaut, L.; Parmentier, M.; Maujean, A.A.; Jeandet, P. Immunodetection of Proteins from Grapes and Yeast in a White Wine. J. Agric. Food Chem. 2003, 51, 2727-2732. [CrossRef] [PubMed]

14. Waters, E.; Alexander, G.; Muhlack, R.; Pocock, K.; Colby, C.; O’Neill, B.; Høj, P.; Jones, P. Preventing protein haze in bottled white wine. Aust. J. Grape Wine Res. 2005, 11, 215-225. [CrossRef]

15. Marangon, M.; Stockdale, V.J.; Munro, P.; Trethewey, T.; Schulkin, A.; Holt, H.E.; Smith, P.A. Addition of Carrageenan at Different Stages of Winemaking for White Wine Protein Stabilization. J. Agric. Food Chem. 2013, 61, 6516-6524. [CrossRef]

16. Waters, E.J.; Wallace, W.; Williams, P.J. Identification of heat-unstable wine proteins and their resistance to peptidases. J. Agric. Food Chem. 1992, 40, 1514-1519. [CrossRef] 
17. Marangon, M.; Sauvage, F.-X.; Waters, E.J.; Vernhet, A. Effects of Ionic Strength and Sulfate upon Thermal Aggregation of Grape Chitinases and Thaumatin-like Proteins in a Model System. J. Agric. Food Chem. 2011, 59, 2652-2662. [CrossRef]

18. Cosme, F.; Fernandes, C.; Ribeiro, T.; Filipe-Ribeiro, L.; Nunes, F.M. White Wine Protein Instability: Mechanism, Quality Control and Technological Alternatives for Wine Stabilisation-An Overview. Beverages 2020, 6, 19. [CrossRef]

19. Blade, W.; Boulton, R. Adsorption of protein by bentonite in a model wine solution. Am. J. Enol. Vitic. 1988, 39, 193-199.

20. Achaerandio, I.; Pachova, V.; Güell, C.; López, F. Protein adsorption by bentonite in a white wine model solution: Efect of protein molecular weight and ethanol concentration. Am. J. Enol. Vitic. 2001, 52, 122-126.

21. Lambri, M.; Dordoni, R.; Silva, A.; De Faveri, D.M. Comparing the impact of bentonite addition for both must clarification and wine fining on the chemical profile of wine from Chambave Muscat grapes. Int. J. Food Sci. Technol. 2011, 47, 1-12. [CrossRef]

22. Waters, E.J.; Shirley, N.J.; Williams, P.J. Nuisance Proteins of Wine Are Grape Pathogenesis-Related Proteins. J. Agric. Food Chem. 1996, 44, 3-5. [CrossRef]

23. Lambri, M.; Dordoni, R.; Silva, A.; De Faveri, D.M. Odoractive compound adsorption onto bentonite in a model white wine solution. Chem. Eng. Trans. 2013, 32, 1741-1746. [CrossRef]

24. Dordoni, R.; Colangelo, D.; Giribaldi, M.; Giuffrida, M.G.; De Faveri, D.M.; Lambri, M. Effect of Bentonite Characteristics on Wine Proteins, Polyphenols, and Metals under Conditions of Different pH. Am. J. Enol. Vitic. 2015, 66, 518-530. [CrossRef]

25. Vincenzi, S.; Panighel, A.; Gazzola, D.; Flamini, R.; Curioni, A. Study of Combined Effect of Proteins and Bentonite Fining on the Wine Aroma Loss. J. Agric. Food Chem. 2015, 63, 2314-2320. [CrossRef] [PubMed]

26. Lambri, M.; Dordoni, R.; Silva, A.; Faveri, D.M. Efect of bentonite fining on odor-active compounds in two diferent white wine styles. Am. J. Enol. Vitic. 2010, 61, 225-233.

27. Tattersall, D.B.; Pocock, K.F.; Hayasaka, Y.; Adams, K.; Van Heeswijck, R.; Waters, E.J.; Høj, P.B. Pathogenesis Related ProteinsTheir Accumulation in Grapes during Berry Growth and Their Involvement in White Wine Heat Instability. Current Knowledge and Future Perspectives in Relation to Winemaking Practices. Mol. Biol. Biotechnol. Grapevine 2001, 183-201. [CrossRef]

28. Majewski, P.; Barbalet, A.; Waters, E.J. \$1 billion hidden cost of bentonite fining. Aust. N.Z. Grapegrow. Winemak. 2011, 569, 61-62.

29. Vincenzi, S.; Polesani, M.; Curioni, A. Removal of specific protein compounds by chitin enhanced protein stability in white wine. Am. J. Enol. Vitic. 2005, 56, 246-254.

30. Colangelo, D.; Torchio, F.; De Faveri, D.M.; Lambri, M. The use of chitosan as alternative to bentonite for wine fining: Effects on heat-stability, proteins, organic acids, colour, and volatile compounds in an aromatic white wine. Food Chem. 2018, 264, 301-309. [CrossRef] [PubMed]

31. Ratnayake, S.; Stockdale, V.; Grafton, S.; Munro, P.; Robinson, A.; Pearson, W.; McRae, J.; Bacic, A. Carrageenans as heat stabilisers of white wine. Aust. J. Grape Wine Res. 2019, 25, 439-450. [CrossRef]

32. Ribeiro, T.; Fernandes, C.; Nunes, F.; Filipe-Ribeiro, L.; Cosme, F. Influence of the structural features of commercial mannoproteins in white wine protein stabilization and chemical and sensory properties. Food Chem. 2014, 159, 47-54. [CrossRef]

33. Gonzalez-Ramos, D.; Cebollero, E.; Gonzalez, R. A Recombinant Saccharomyces cerevisiae Strain Overproducing Mannoproteins Stabilizes Wine against Protein Haze. Appl. Environ. Microbiol. 2008, 74, 5533-5540. [CrossRef] [PubMed]

34. European Union (EU). Commission regulation (EU) 53/2011 of 21 January 2011. Available online: https: / / eurlex.euro-pa.eu/ LexUriServ/LexUriServ.do?uri=OJ:L:2011:019:0001:0006:EN:PDF (accessed on 18 December 2020).

35. OIV. International Code of Oenological Practices. International Organisation of Vine and Wine. 2019. Available online: http: / / www.oiv.int/fr/normes-et-documents-techniques (accessed on 20 December 2020).

36. Bowman, S.M.; Free, S.J. The structure and synthesis of the fungal cell wall. BioEssays 2006, 28, 799-808. [CrossRef]

37. Hamed, I.; Özogul, F.; Regenstein, J.M. Industrial applications of crustacean by-products (chitin, chitosan, and chitooligosaccharides): A review. Trends Food Sci. Technol. 2016, 48, 40-50. [CrossRef]

38. Vincenzi, S.; Mosconi, S.; Zoccatelli, G.; Pellegrina, C.D.; Veneri, G.; Chignola, R.; Peruo, A.; Curioni, A.; Rizzi, C. Development of a new procedure for protein recovery and quantification in wine. Am. J. Enol. Vitic. 2005, 56, 182-187.

39. Cabello-Pasini, A.; Victoria-Cota, N.; Macias-Carranza, V.; Hernandez-Garibay, E.; Muñiz-Salazar, R. Clarification of wines using polysaccharides extracted from seaweeds. Am. J. Enol. Vitic. 2005, 56, 52-59.

40. Marangon, M.; Lucchetta, M.; Duan, D.; Stockdale, V.; Hart, A.; Rogers, P.; Waters, E. Protein removal from a Chardonnay juice by addition of carrageenan and pectin. Aust. J. Grape Wine Res. 2012, 18, 194-202. [CrossRef]

41. Vidal, S.; Williams, P.; Doco, T.; Moutounet, M.; Pellerin, P. The polysaccharides of red wine: Total fractionation and characterization. Carbohydr. Polym. 2003, 54, 439-447. [CrossRef]

42. Gawel, R.; Smith, P.A.; Waters, E.J. Influence of polysaccharides on the taste and mouthfeel of white wine. Aust. J. Grape Wine Res. 2016, 22, 350-357. [CrossRef]

43. Jones, P.; Gawel, R.; Francis, I.; Waters, E. The influence of interactions between major white wine components on the aroma, flavour and texture of model white wine. Food Qual. Prefer. 2008, 19, 596-607. [CrossRef]

44. Martínez-Lapuente, L.; Guadalupe, Z.; Ayestarán, B. Properties of Wine Polysaccharides. In Pectins-Extraction, Purification, Characterization and Applications; InTech: London, UK, 2020.

45. Waters, E.J.; Pellerin, P.; Brillouet, J.-M. A Saccharomyces mannoprotein that protects wine from protein haze. Carbohydr. Polym. 1994, 23, 185-191. [CrossRef]

46. Moine-Ledoux, V.; Dubourdieu, D. An invertase fragment responsible for improving the protein stability ofdry white wines. $J$. Sci. Food Agric. 1999, 79, 537-543. [CrossRef] 
47. Gawel, R.; Day, M.; Van Sluyter, S.C.; Holt, H.; Waters, E.J.; Smith, P.A. White Wine Taste and Mouthfeel As Affected by Juice Extraction and Processing. J. Agric. Food Chem. 2014, 62, 10008-10014. [CrossRef]

48. Jaeckels, N.; Meier, M.; Dietrich, H.; Will, F.; Decker, H.; Fronk, P. Influence of polysaccharides on wine protein aggregation. Food Chem. 2016, 200, 38-45. [CrossRef] [PubMed]

49. Read, S.; Northcote, D. Minimization of variation in the response to different proteins of the Coomassie blue G dye-binding assay for protein. Anal. Biochem. 1981, 116, 53-64. [CrossRef]

50. Pocock, K.F.; Hayasaka, Y.; McCarthy, A.M.G.; Waters, E.J. Thaumatin-like Proteins and Chitinases, the Haze-Forming Proteins of Wine, Accumulate during Ripening of Grape (Vitis vinifera) Berries and Drought Stress Does Not Affect the Final Levels per Berry at Maturity. J. Agric. Food Chem. 2000, 48, 1637-1643. [CrossRef] [PubMed]

51. Salazar, F.N.; López, F.; Chiffelle, I.; Lopez, R.; Peña-Neira, Á. Evaluation of pathogenesis-related protein content and protein instability of seven white grape (Vitis vinifera L.) clones from Casablanca Valley, Chile. Eur. Food Res. Technol. 2012, 234, 509-515. [CrossRef]

52. Dubourdieu, D.; Serrano, M.; Vannier, A.C.; Ribéreau-Gayon, P. Étude comparée des tests de stabilité protéique. Conn. Vigne Vin 1988, 22, 261-273. [CrossRef]

53. Descout, J.J.; Bordier, J.L.; Laurenty, J.; Guimberteau, G. Contribution a l'etude des phenomenes de colmatage lors de la filtration des vins sur filtre ecran. Conn. Vigne Vin 1976, 10, 93-123. [CrossRef]

54. Kramling, T.; Singleton, V.L. An estimate of the nonflavonoid phenols in wines. Am. J. Enol. Vitic. 1969, $20,86-92$.

55. Ribéreau-Gayon, P.; Peynaud, E.; Sudraud, P. Traité d'OEnologie. In Science et Techniques du Vin; Tome 4; Dunod: Paris, France, 1982 ; p. 643.

56. OIV. Organisation International de la Vigne et du Vin Récueil deMéthodes Internationales d'Analyse des Vins et des Moûts. Edition O/methodes-danalyse. Available online: https://www.oiv.int/fr/normes-et-documents-techniques/methodes-danalyse/ recueil-des-methodes-internationales-danalyse-des-vins-et-des-mouts-2-vol (accessed on 20 December 2020).

57. Spagna, G.; Pifferi, P.G.; Rangoni, C.; Mattivi, F.; Nicolini, G.; Palmonari, R. The stabilization of white wines by adsorption of phenolic compounds on chitin and chitosan. Food Res. Int. 1996, 29, 241-248. [CrossRef]

58. Guise, R.; Filipe-Ribeiro, L.; Nascimento, D.; Bessa, O.; Nunes, F.; Cosme, F. Comparison between different types of carboxylmethylcellulose and other oenological additives used for white wine tartaric stabilization. Food Chem. 2014, 156, 250-257. [CrossRef]

59. Filipe-Ribeiro, L.; Milheiro, J.; Matos, C.C.; Cosme, F.; Nunes, F.M. Reduction of 4-ethylphenol and 4-ethylguaiacol in red wine by activated carbons with different physicochemical characteristics: Impact on wine quality. Food Chem. 2017, 229, 242-251. [CrossRef]

60. Filipe-Ribeiro, L.; Milheiro, J.; Matos, C.C.; Cosme, F.; Nunes, F.M. Data on changes in red wine phenolic compounds, headspace aroma compounds and sensory profile after treatment of red wines with activated carbons with different physicochemical characteristics. Data Brief. 2017, 12, 188-202. [CrossRef] [PubMed]

61. Fraga, S.M.; Nunes, F.M. Agaricus bisporus By-Products as a Source of Chitin-Glucan Complex Enriched Dietary Fibre with Potential Bioactivity. Appl. Sci. 2020, 10, 2232. [CrossRef]

62. Batista, L.; Monteiro, S.; Loureiro, V.B.; Teixeira, A.R.; Ferreira, R.B. The complexity of protein haze formation in wines. Food Chem. 2009, 112, 169-177. [CrossRef]

63. Mesquita, P.R.; Piçarra-Pereira, M.A.; Monteiro, S.; Loureiro, V.B.; Teixeira, A.R.; Ferreira, R.B. Effect of wine composition on protein stability. Am. J. Enol. Vitic. 2001, 52, 324-330.

64. Pellerin, P.; Cabanis, J.-C. Les Glucides. In CEnologie. Fondements Scientifiques et Technologiques; Flanzy, C., Ed.; Lavoisier- Tec \& Doc: Paris, France, 1998.

65. Doco, T.; Williams, P.; Moutounet, M.; Pellerin, P. Les polysaccharides du vin. Bulletin l'O.I.V. 2000, 73, 785-792.

66. Tian, B.; Harrison, R.; Morton, J.D.; Jaspers, M.V.; Hodge, S.; Grose, C.; Trought, M.C. Extraction of Pathogenesis-Related Proteins and Phenolics in Sauvignon Blanc as Affected by Grape Harvesting and Processing Conditions. Molecules 2017, $22,1164$. [CrossRef] [PubMed]

67. Marangon, M.; Van Sluyter, S.C.; Haynes, P.A.; Waters, E.J. Grape and Wine Proteins: Their Fractionation by Hydrophobic Interaction Chromatography and Identification by Chromatographic and Proteomic Analysis. J. Agric. Food Chem. 2009, 57, 4415-4425. [CrossRef] [PubMed]

68. Sęczyk, Ł.; Świeca, M.; Kapusta, I.; Gawlik-Dziki, U. Protein-Phenolic Interactions as a Factor Affecting the Physicochemical Properties of White Bean Proteins. Molecules 2019, 24, 408. [CrossRef]

69. Gabrielli, M.; Fracassetti, D.; Tirelli, A. Release of phenolic compounds from cork stoppers and its effect on protein-haze. Food Control. 2016, 62, 330-336. [CrossRef]

70. Falconer, R.J.; Marangon, M.; Van Sluyter, S.C.; Neilson, K.A.; Chan, C.; Waters, E.J. Thermal Stability of Thaumatin-Like Protein, Chitinase, and Invertase Isolated from Sauvignon blanc and Semillon Juice and Their Role in Haze Formation in Wine. J. Agric. Food Chem. 2010, 58, 975-980. [CrossRef]

71. Bayly, F.C.; Berg, H.W. Grape and wine proteins of white wine varietals. Am. J. Enol. Vitic. 1967, 24, 18-32.

72. Moretti, R.H.; Berg, H.W. Variability among wines to protein clouding. Am. J. Enol. Vitic. 1965, 16, 69-78.

73. Waters, E.J.; Hayasaka, Y.; Tattersall, D.B.; Adams, K.S.; Williams, P.J. Sequence Analysis of Grape (Vitis vinifera) Berry Chitinases That Cause Haze Formation in Wines. J. Agric. Food Chem. 1998, 46, 4950-4957. [CrossRef] 
74. Esteruelas, M.; Poinsaut, P.; Sieczkowski, N.; Manteau, S.; Fort, M.; Canals, J.; Zamora, F. Characterization of natural haze protein in sauvignon white wine. Food Chem. 2009, 113, 28-35. [CrossRef]

75. Dufrechou, M.; Poncet-Legrand, C.; Sauvage, F.-X.; Vernhet, A. Stability of White Wine Proteins: Combined Effect of pH, Ionic Strength, and Temperature on Their Aggregation. J. Agric. Food Chem. 2012, 60, 1308-1319. [CrossRef]

76. Sun, B.; Spranger, I.; Roque-Do-Vale, F.; Leandro, C.; Belchior, P. Effect of Different Winemaking Technologies on Phenolic Composition in Tinta Miúda Red Wines. J. Agric. Food Chem. 2001, 49, 5809-5816. [CrossRef]

77. Guadalupe, Z.; Martínez, L.; Ayestarán, B. Yeast mannoproteins in red winemaking: Effect on polysaccharide, polyphenolic, and color composition. Am. J. Enol. Vitic. 2010, 61, 191-200.

78. De Vries, R.P.; Visser, J. Aspergillus Enzymes Involved in Degradation of Plant Cell Wall Polysaccharides. Microbiol. Mol. Biol. Rev. 2001, 65, 497-522. [CrossRef] [PubMed]

79. Guadalupe, Z.; Ayestarán, B.; Williams, P.; Doco, T. Determination of Must and Wine Polysaccharides by Gas. Chromatography-Mass Spectrometry (GC-MS) and Size-Exclusion Chromatography (SEC); Springer International Publishing: Berlin/Heidelberg, Germany, 2014; pp. 1-28.

80. Thompson, J.E.; Fry, S.C. Evidence for covalent linkage between xyloglucan and acidic pectins in suspension-cultured rose cells. Planta 2000, 211, 275-286. [CrossRef] [PubMed]

81. Doco, T.; Williams, P.; Pauly, M.; O’Neill, M.A.; Pellerin, P. Polysaccharides from grape berry cell walls. Part II. Structural characterization of the xyloglucan polysaccharides. Carbohydr. Polym. 2003, 53, 253-261. [CrossRef]

82. Vernhet, A.; Pellerin, P.; Prieur, C.; Osmianski, J.; Moutounet, M. Charge properties of some grape and wine polysaccharide and polyphenolic fractions. Am. J. Enol. Vitic. 1996, 47, 25-30. 